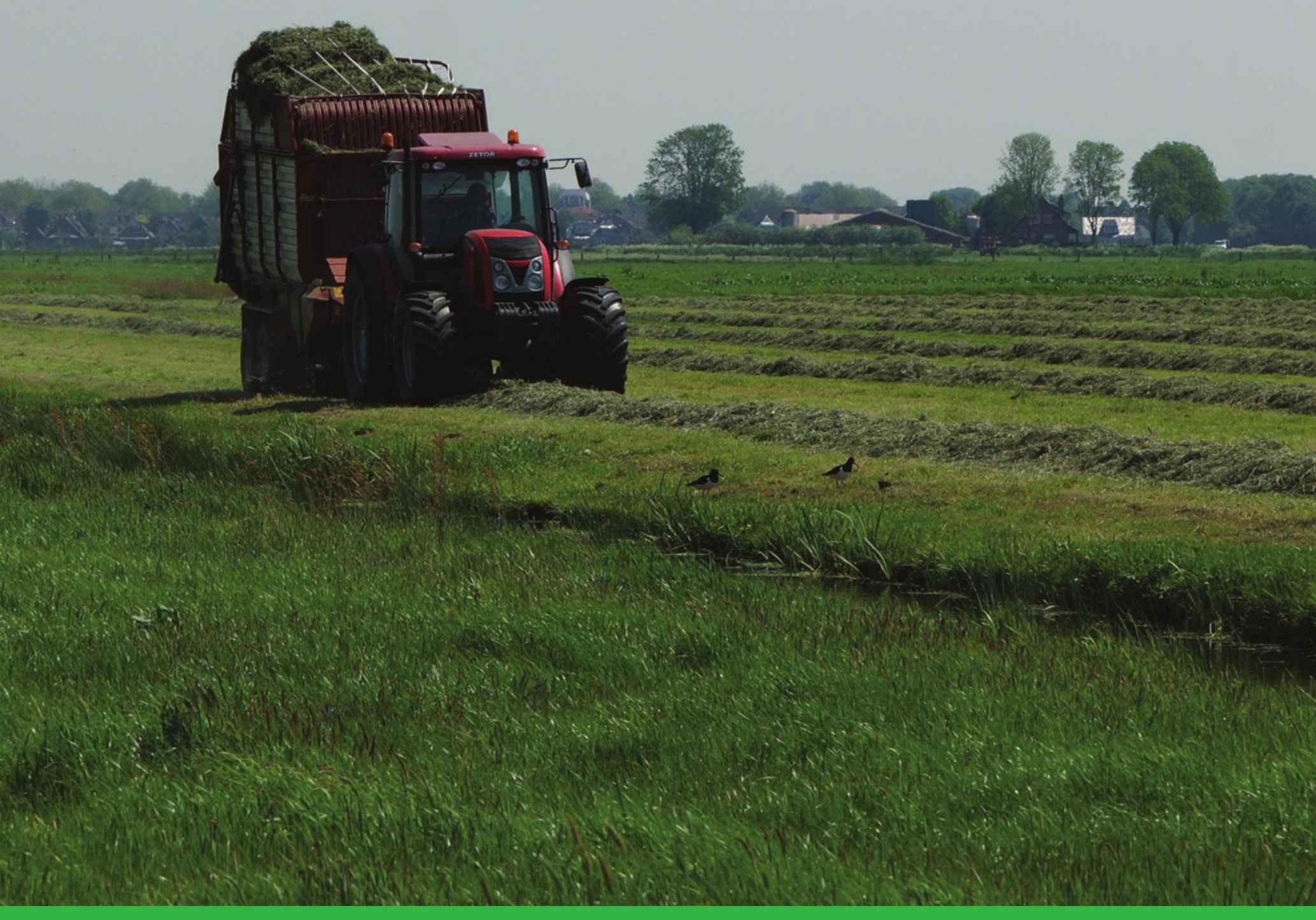

\title{
Rapportage werkzaamheden kennissysteem BoM 2017
}

Dick Melman, Tim Visser, Igor Staritsky 



\section{Rapportage werkzaamheden kennissysteem BoM 2017}

Dick Melman, Tim Visser, Igor Staritsky

Dit onderzoek is uitgevoerd door Wageningen Environmental Research in opdracht van en gefinancierd door het ministerie van Landbouw, Natuur en Voedselkwaliteit, in het kader van het Beleidsondersteunend onderzoekthema 'lerend beheer voor rendement ANLb' (BO-11-020-008).

Wageningen Environmental Research

Wageningen, februari 2018

Rapport 2865

ISSN 1566-7197 
Melman, Th.C.P., T. Visser en I. Staritsky, 2018. Rapportage werkzaamheden kennissysteem BoM 2017. Wageningen, Wageningen Environmental Research, Rapport 2865. 50 blz.; 8 fig.; 6 tab.; 19 ref.

Het kennissysteem voor Agrarisch Natuurbeheer, Beheer-op-Maat (BoM), is op een aantal punten aangepast aan wensen van gebruikers (beheercollectieven). Deze wensen waren naar voren gekomen tijdens werkplaatsen, bezocht door negentien collectieven. De collectieven waren kritisch en positief over de mogelijke betekenis van BoM voor de beheerpraktijk. De wensen hebben betrekking op de gebruiksvriendelijkheid, de ontsluiting van nieuwe informatielagen en de inhoudelijke transparantie van het kennissysteem. Daartoe is wegens technische-inhoudelijke noodzaak de webtool omgezet van Flash naar Ext JS 6.5 (een javascript library). Om voor de praktijk blijvend van betekenis te zijn, is belangrijk dat gegevens actueel en betrouwbaar zijn. Dit dient organisatorisch geregeld te zijn. Voor een breed draagvlak voor BoM is bewaking door een breed, onafhankelijk gremium belangrijk. Aan validatie van BoM dient blijvend aandacht te worden geschonken. Na weidevogels kunnen ook de andere leefgebiedtypen in het kennissysteem worden opgenomen. Voor deze leefgebiedtypen zal ook aan kennisontwikkeling aandacht geschonken moeten worden.

The knowledge system for Agricultural Nature Management, Management-to-Measure (BoM), has been adapted in a number of ways to the wishes of users (management collectives). These wishes emerged during workshops, visited by 19 collectives. The collectives were critical and positive about the possible meaning of BoM for their management practice. The wishes relate to the user-friendliness, the opening up of new information layers and the transparency of calculations by the knowledge system. To this end, Flash has been converted to Ext JS 6.5 (a javascript library) due to technical urgency. In order to remain meaningful for practice, it is important that data is up-to-date and reliable. This must be organized. For a broad support base for BoM, monitoring by a broad independent body is important. Continuously attention must be paid to validation of BoM. After meadow birds, the other habitat types can also be included in the knowledge system: arable fields, dry en wet veining structures. For these habitat types, much attention should also be paid to knowledge development.

Trefwoorden: Agrarisch natuurbeheer, collectieven, weidevogels, kennissysteem

Het rapport is gereviewd door dr. R. Buij.

Dit rapport is gratis te downloaden van https://doi.org/10.18174/441468 of op

www.wur.nl/environmental-research (ga naar 'Wageningen Environmental Research' in de grijze balk onderaan). Wageningen Environmental Research verstrekt geen gedrukte exemplaren van rapporten.

2018 Wageningen Environmental Research (instituut binnen de rechtspersoon Stichting Wageningen Research), Postbus 47, 6700 AA Wageningen, T 03174807 00, www.wur.nl/environmental-research. Wageningen Environmental Research is onderdeel van Wageningen University \& Research.

- Overname, verveelvoudiging of openbaarmaking van deze uitgave is toegestaan mits met duidelijke bronvermelding.

- Overname, verveelvoudiging of openbaarmaking is niet toegestaan voor commerciële doeleinden en/of geldelijk gewin.

- Overname, verveelvoudiging of openbaarmaking is niet toegestaan voor die gedeelten van deze uitgave waarvan duidelijk is dat de auteursrechten liggen bij derden en/of zijn voorbehouden.

Wageningen Environmental Research aanvaardt geen aansprakelijkheid voor eventuele schade voortvloeiend uit het gebruik van de resultaten van dit onderzoek of de toepassing van de adviezen.

Wageningen Environmental Research Rapport 2865 | ISSN 1566-7197

Foto omslag: Grasoogst met groot materieel; een paartje scholeksters aan de slootkant. Het maaien, schudden, op wiersen leggen en afvoeren van gras voltrekt zich binnen enkele dagen. Met name jonge weidevogels lopen dan grote risiko's. Als ze het al overleven vormen ze voor predatoren een gemakkelijke prooi, omdat schuilgelegenheid ontbreekt. Een late maaidatum kan uitkomst brengen. Een greppelplas-dras kan het positieve effect ervan versterken. (foto: Dick Melman) 


\section{Inhoud}

$\begin{array}{ll}\text { Samenvatting } & \mathbf{5}\end{array}$

$\begin{array}{ll}1 & \text { Inleiding }\end{array}$

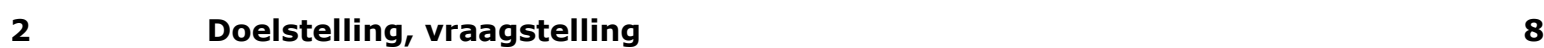

$3 \quad$ Methode, uitvoering $\quad 9$

$\begin{array}{lrr}\text { Resultaten } & 10\end{array}$

4.1 Input vanuit de werkplaatsen $\quad 10$

4.2 Realisatie technische verbeteringen 11

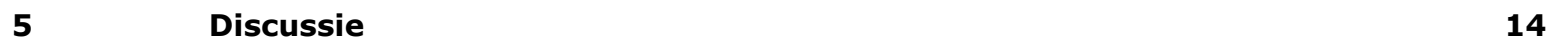

$\begin{array}{llr}6 & \text { Conclusies en aanbevelingen } & 17\end{array}$

$\begin{array}{ll}\text { Literatuur } & 18\end{array}$

Bijlage 1 Handleiding Beheer op Maat $\quad 20$

$\begin{array}{lll}\text { Bijlage } 2 & \text { Verslag werkplaatsen BoM } & 37\end{array}$

$\begin{array}{lll}\text { Bijlage } 3 & \text { Voorstel voor kentallen BoM } & 44\end{array}$

$\begin{array}{lll}\text { Bijlage } 4 & \text { Samenvatting onderzoek greppel plas-dras } & 46\end{array}$ 



\section{Samenvatting}

Voor een effectief agrarisch natuurbeheer is goede ontsluiting van kennis cruciaal. Voor beheerders zijn wetenschappelijke publicaties doorgaans niet toegankelijk. Door het toegankelijk maken en delen van kennis over soorten, gebieden en beheermaatregelen kan het lerend beheer vorm krijgen en verder ontwikkeld worden. In voorgaande jaren is er gewerkt aan het kennissysteem agrarisch natuurbeheer Beheer-op-Maat (BoM). Dat ontsluit beschikbare, ecologisch relevante informatie op een voor beheerders laagdrempelige wijze. Het accent ligt tot nog toe op het weidevogelbeheer.

BoM is inhoudelijk al redelijk ver ontwikkeld. Het is gebaseerd op literatuur en waar die afwezig is, op professional judgements, al of niet gedeeld met vakgenoten. Het is belangrijk om te weten of het voor de dagelijkse praktijk van de collectieven ook werkt. Essentieel bij het verder ontwikkelen, is zicht te hebben op de bevindingen van de gebruikers en hun wensen (zowel inhoudelijk als qua gebruiksvriendelijkheid). Daartoe is samenwerking gezocht met BoerennatuurNL (BNL) en Hogeschool Van Hall Larenstein (HVHL), die zeven werkplaatsen heeft georganiseerd. Deze werkplaatsen zijn door negentien collectieven bezocht. De collectieven waren kritisch en positief over de mogelijke betekenis van BoM voor de beheerpraktijk. Er is een aantal wensen naar voren gebracht. Deze hebben betrekking op de gebruiksvriendelijkheid, de toevoeging van nieuwe informatielagen (bijv. bodemkaart) en de inhoudelijke transparantie van het kennissysteem (de gehanteerde algoritmes). Het kennissysteem voor Agrarisch Natuurbeheer, Beheer-op-Maat (BoM), is op een aantal punten aangepast aan deze wensen.

Een vrij omvangrijke operatie was de omzetting van de webtool van Flash naar Ext JS 6.5 (een javascript library). Dit was noodzakelijk om technisch-inhoudelijke redenen (Flash verdwijnt op korte termijn).

Uit de reactie van de gebruikers vloeien de volgende aanbevelingen voort:

- Om voor de praktijk blijvend van betekenis te zijn, is belangrijk dat gegevens actueel en betrouwbaar zijn (omgevingskenmerken, beheer, aanwezigheid weidevogels). Dit dient organisatorisch geregeld te worden.

- Voor een breed draagvlak voor BoM is bewaking door een breed, onafhankelijk gremium belangrijk.

- Aan validatie van BoM dient blijvend aandacht te worden geschonken.

- Na weidevogels kunnen ook de andere leefgebiedtypen in het kennissysteem worden opgenomen. Voor deze leefgebiedtypen zal niet alleen kennisontsluiting aan de orde zijn, maar zal ook aan kennisontwikkeling aandacht geschonken moeten worden. 


\section{$1 \quad$ Inleiding}

Voor een effectief agrarisch natuurbeheer is goede ontsluiting van kennis cruciaal. Door het toegankelijk maken en delen van kennis over soorten, gebieden en beheermaatregelen kan het lerend beheer vorm krijgen en verder ontwikkeld worden. In voorgaande jaren is er gewerkt aan het kennissysteem agrarisch natuurbeheer Beheer-op-Maat (BoM). Dat ontsluit beschikbare ecologisch relevante informatie op een voor beheerders laagdrempelige wijze. Het accent ligt tot nog toe op het weidevogelbeheer.

BoM is inhoudelijk al redelijk ver ontwikkeld. Het is belangrijk om te weten of het voor de praktijk van de collectieven ook kan werken; essentieel bij het verder ontwikkelen van BoM is zicht te hebben op de bevindingen van de gebruikers en hun wensen. Daartoe is samenwerking gezocht met BoerennatuurNL (BNL) en Hogeschool Van Hall Larenstein (HVHL). Daar bleek belangstelling voor te zijn. De ex-ante-evaluatie ANLb-2016, waarin de beheerplannen van de collectieven op ligging, ruimtelijke samenhang en kwaliteit zijn geëvalueerd (Melman et al. 2016), was voor de collectieven aanleiding om de inzet van het beheer te verbeteren.

Door HVHL en BNL is het initiatief genomen om een aantal werkplaatsen te organiseren, gericht op de verbetering van de weidevogelbeheerplannen. Daarbij wilden ze graag gebruikmaken van BoM. Dat paste precies bij de scope van onderhavig project. In deze werkplaatsen stond lerend beheren centraal en ze hadden tevens als doel bij te dragen aan het werken aan één taal en begrippenset voor het weidevogelbeheer, waaraan overigens door alle betrokkenen een groot belang wordt toegekend. De bijeenkomsten leverden inzicht in de toegankelijkheid en bruikbaarheid van BoM en boden tevens de gelegenheid om verbeterwensen te inventariseren.

De opbrengst van de werkplaatsen was de voeding voor de werkzaamheden zoals die in onderhavig project zijn opgepakt en uitgevoerd.

Het kennissysteem agrarisch natuurbeheer in het kort

(voor een overzicht van de rapportages, zie literatuur, aangeduid met $*$ )

Het kennissysteem ontsluit ecologische kennis voor de leefgebiedtypen die in het ANB relevant zijn. Het is opgenomen in een GIS. Het omvat:

- Kennisregels voor het vaststellen van de potentiële habitatkwaliteit (geïntegreerde beoordeling van diverse habitatfactoren);

- Kennisregels voor de bepaling van de gerealiseerde habitatkwaliteit door beheer (geïntegreerde beoordeling potentiële habitatkwaliteit + beheerregime);

- Indicatoren voor toereikendheid van het habitat voor weidevogelgezinnen (geïntegreerde beoordeling van de in het gebied gerealiseerde habitatkwaliteit in relatie tot de aanwezige territoria);

- Mogelijkheden om door externen geleverde informatie te gebruiken (bijv. RVO-bestanden met het beheer) en informatie over de aanwezigheid van weidevogelsoorten (bijvoorbeeld info van SOVON, De Landschappen);

- Mogelijkheden voor toevoegen van eigen gegevens over beheer en voorkomen van soorten;

- Kansrijkdomkaarten (gebaseerd op verspreiding soorten en gebiedseigenschappen);

- Soorten fiches (identiek aan die van www.portaalnatuurenlandschap).

PM: (wel conceptueel ontwikkeld, nog niet in het systeem opgenomen):

- indicatoren voor ruimtelijke concentratie van beheer per leefgebiedtype;

- indicatoren voor ruimtelijke samenhang tussen beheer van verschillende leefgebiedtypen.

Het kennissysteem kan gebieden karakteriseren met behulp van kentallen, onder andere: omvang, potentiële habitatkwaliteit, areaal verschillende beheervormen, gerealiseerde habitatkwaliteit, dichtheid territoria, beschikbaarheid habitat per territorium.

Het kennissysteem is online benaderbaar (met gebruikersnaam en wachtwoord) en biedt collectieven de mogelijkheid om bovenstaande zaken voor het eigen gebied uit te zoeken. 


\section{Doelstelling, vraagstelling}

Doelstelling 1: de eerste doelstelling van het project is om in samenspraak met de collectieven een beeld te vormen van de bruikbaarheid van het kennissysteem voor lerend beheer en waar nodig te verbeteren, voor de verdere versterking van de ecologische effectiviteit van het agrarisch natuurbeheer. De uiteindelijke vraag is of het kennissysteem een geschikt vehikel is om voor de praktijk van het agrarisch natuurbeheer te komen tot één gedeelde taal en tot één set grens- en streefwaarden die door alle betrokkenen worden onderschreven en vastgesteld.

Hoe het proces van lerend beheer verloopt, is bij dit alles ook een belangrijk aandachtspunt. Het gaat om vragen als: wat zien collectieven als belangrijke kennis om tot goede beheerplannen te komen en in hoeverre wordt dit door het kennissysteem adequaat aangereikt? En hoe verhoudt dit zich met de ecologisch-wetenschappelijke inzichten? Is het kennissysteem voldoende flexibel om in specifieke gebiedssituaties te worden toegepast? Biedt het voldoende mogelijkheden om specifiek gebiedskennis toe te voegen? Zien de collectieven het als praktisch hulpmiddel voor lerend beheer? Welke aanpassingen worden gewenst om de bruikbaarheid voor het lerend beheer en de verbetering van het agrarisch natuurbeheer te versterken? Deze vragen worden tijdens de bijeenkomsten met de collectieven aan de orde gesteld. Daarmee ontstaat tijdens het project inzicht in hoeverre het lerend beheer van de grond komt en welke functie het kennissysteem hierin heeft of zou kunnen hebben.

Doelstelling 2: Aansluitend op doelstelling 1 geldt er voor BoM een aantal technische doelstellingen die binnen dit project gerealiseerd moeten worden. Een belangrijk onderdeel hiervan is het omzetten van BoM van Flash naar Ext JS 6.5 (een javascript library). Dit omdat Flash inmiddels verouderd is en niet meer door alle webbrowsers wordt ondersteund en op korte termijn zelfs helemaal verdwijnt. Ten slotte is het aanpassen van de webapplicatie (indeling, functies etc.) naar de wensen van gebruikers een belangrijke doelstelling. Welke vorm deze doelstelling aanneemt, is geheel afhankelijk van de te verkrijgen feedback zoals in doelstelling 1 verwoord.

Additionele doelstelling: onderzoek betekenis plas-dras voor weidevogelkuikens. Vanuit het collectief Ark en Eemlandschap kwam de vraag of BoM voldoende aandacht schenkt aan de waarde van greppelplas-dras als element in het weidevogelbeheer. Een interessante en belangrijke vraag, omdat plas-drassituaties voor de inpasbaarheid van het weidevogelbeheer interessante perspectieven bieden. Omdat zich een student aandiende die dit onderzoek op zich wilde nemen, kon er ruimte voor worden gevonden. In deze rapportage nemen we de samenvatting op (zie Bijlage 4). Aan het onderzoek is een afzonderlijk rapport gewijd (Visser et al. 2017). 


\section{Methode, uitvoering}

Verbeterwensen BoM

In het project van HVHL/BNL (trekker Astrid Manhoudt) is een zevental werkplaatsen georganiseerd, die bezocht zijn door 19 collectieven.

\section{[Uit het verslag van de werkplaatsen:]}

Het doel van de werkplaatsen was:

1. Inzichtelijk maken van habitatkwaliteiten in voor weidevogels beheerde gebieden; analyse in hoeverre aan 'minimumeisen' wordt voldaan. In hoeverre komt de informatie op de Alterra-kaarten overeen met de eigen gebiedsinzichten?

2. Inzicht creëren in afwegingen/factoren die bepalen op welke locatie een bepaalde beheermaatregel wordt uitgevoerd.

3. Benchmark1 tussen collectieven: vergelijking en bespreking van beheerde gebieden m.b.v. kentallen. Dit om verbeteringsmogelijkheden in aanpak en uitvoering van het beheer scherp te krijgen.

In totaal zijn er 7 werkplaatsen georganiseerd, die bezocht zijn door 19 weidevogelcollectieven en daarnaast door diverse vertegenwoordigers van de provinciale landschappen en/of landschapsbeheerorganisaties (voor aanwezige organisaties zie het overzicht in de Bijlage 1). In elke werkplaats werd aan de hand van drie stappen het kennissysteem uitgelegd:

1. De potentiële habitatkwaliteit ${ }^{2}$

2. De gerealiseerde habitatkwaliteit

3. De geanalyseerde habitatkwaliteit

Tijdens deze bijeenkomsten is BoM gepresenteerd en hebben de collectieven er zelf mee gewerkt om een en ander uit te proberen. De ervaringen zijn plenair teruggekoppeld en besproken. Daarin zijn ook de verbeterwensen aan bod gekomen en vastgelegd. In overleg met Astrid Manhoudt zijn deze wensen geprioriteerd. Deze lijst van verbeterwensen is als input gebruikt om op te pakken bij de verbatering van BoM in onderhavig project.

\section{Technische uitvoering verbeterwensen}

Bij het in uitvoering nemen van de verbeterwensen is met name gelet op de voorziene bijdrage van de verbetering voor praktische betekenis en bruikbaarheid van BoM (in feite een check op de prioritering) en de omvang van het werk dat ermee gemoeid is. Daarmee is gestreefd naar een maximale trade-off van het project qua bruikbaarheid voor de collectieven. Een belangrijk onderscheid daarbij was: wensen die betrekking hadden op het 'bibliotheekdeel' van het kennissysteem (raadpleging basisinformatie) en wensen die betrekking hadden op het 'rekendeel' ervan (berekening habitatkwaliteit i.r.t. inrichting en beheerplannen, hoeveelheid kuikenland per weidevogelgezin). De wensen rond het bibliotheekdeel waren relatief gemakkelijk te realiseren en de wensen die betrekking hadden op het rekendeel vergden eerst een omzetting van het systeem van Flash naar Ext JS 6.5, een omvangrijke operatie. De realisatie van deze wensen moest daarom in de tijd naar achteren worden gezet.

\footnotetext{
${ }^{1}$ Benchmark: een referentiekader om prestaties van bv. organisaties met elkaar te kunnen vergelijken. Benchmarking is een techniek om door middel van vergelijken van elkaar te leren, verantwoording af te leggen en een beeld te krijgen van het prestatieniveau.

2 Voor toelichting op deze begrippen, zie Bijlage 1.
} 


\section{$4 \quad$ Resultaten}

\subsection{Input vanuit de werkplaatsen}

\section{Bevindingen uit werkplaatsen}

Uit het verslag van de werkplaatsen (volledig verslag: Manhoudt en Klein, 2017; zie Bijlage 2):

Tijdens deze werkplaatsen waren de collectieven in het begin zeer kritisch over het kennissysteem, soms nog gebaseerd op eerdere bijeenkomsten rond het kennissysteem, dat toen sterk in ontwikkeling was.

Aan het einde van de werkplaats was iedereen enthousiast en op een betrokken manier met het systeem bezig. Uiteindelijk wilde men graag thuis verder met het systeem aan de slag. Elke werkplaats resulteerde dan ook automatisch in een wensenlijstje van verbeterpunten of nieuwe functies in het systeem.

Collectieven ervaren het werken met Beheer op Maat zinvol: ze kunnen nu op een geobjectiveerde manier kijken naar de basiskwaliteit en de gerealiseerde beheerkwaliteit in hun gebieden. Het kennissysteem brengt concreet in beeld waar verbeteringen in beheer nodig zijn en/of bevestigt dat de collectieven het beheer op orde hebben. Echter, de eigen gebiedskennis van het collectief is essentieel om de basiskwaliteitskaarten en de analyse van het gerealiseerde beheer en de stippen op waarde te schatten en te interpreteren.

De collectieven zien het kennissysteem als een praktisch hanteerbare leidraad om hen te helpen het beheer verder te verbeteren. De collectieven willen het kennissysteem graag gebruiken voor verschillende doeleinden bij het weidevogelbeheer:

- Het plannen van het beheer;

- Evaluatie van het jaarlijkse beheer;

- Het verbeteren van het last minute beheer ${ }^{3}$;

- Het invullen en uitwerken van het beheer in compensatiegebieden ${ }^{4}$;

- Onderbouwen van noodzakelijk wijzigingen in beheer per deelnemer of per gebied;

- Verantwoorden aan derden, zoals provincies, vrijwilligersorganisaties en gebiedspartijen zoals terreinbeherende organisaties.

Het kennissysteem kan de collectieven helpen in de communicatie naar diverse partijen, zoals de eigen deelnemers, nieuwe deelnemers, terreinbeheerders, provincie of andere overheden. Het systeem maakt inzichtelijk hoe het beheer georganiseerd is, welke verbeteringen in het beheer nodig zijn en/of soms andersom: welke beheer overbodig is in een bepaald gebied.

Hiermee worden verbeterpunten zichtbaar; de collectieven vinden het echter niet wenselijk dat de overheid dit systeem als een beoordelingsmiddel gaat gebruiken, maar dat het een tool blijft voor de collectieven om de gebieden met beheer beter in kaart te brengen, de eigen gebieden te kunnen toetsen, maar ook gebieden tussen collectieven te kunnen benchmarken.

Het kennissysteem maakt duidelijk dat het werken met actuele, betrouwbare en nauwkeurige gegevens essentieel is. Veel opmerkingen tijdens de werkplaatsen hebben betrekking op niet-volledige of niet-actuele gegevens. De juiste gegevens moeten actueel beschikbaar zijn om een zinvolle analyse uit te kunnen voeren. Hier ligt een opgave!

Daarnaast moeten de gegevens eenduidig zijn: een uniforme aanpak van de beheermonitoring is hiervoor de basis. Door samen te werken met andere collectieven, LandschappenNL en SOVON, kunnen hier de komende tijd nog stappen in gemaakt worden.

De kaarten en de analyses bevestigen vaak wat de collectieven zelf al van hun gebieden weten, maar zijn op onderdelen soms niet up-to-date en daardoor niet 100\% betrouwbaar (bijvoorbeeld verwijderen van bomen; nieuwbouw). Zonder de eigen gebiedskennis van het collectief kunnen de basiskwaliteitskaarten niet volledig op waarde worden geschat of geïnterpreteerd.

\footnotetext{
3 Beheer dat tijdens het seizoen wordt overeengekomen inspelend op de actuele situatie (bijvoorbeeld aanwezigheid foeragerende gezinnen, waardoor uitstel maaidatum daar zeer gewenst en urgent is).

4 Gebieden waar extra natuur wordt gecreëerd in verband met elders toegebrachte schade aan natuur.
} 


\section{Wensen voor verbeteringen BoM}

In de werkplaatsen zijn door de collectieven tal van verbetersuggesties gegeven. Deze hebben zowel op het kennissysteem zelf betrekking als op de organisatie van de ontsluiting van de benodigde gegevens. De verbetersuggesties voor het kennissysteem Beheer op Maat gingen over:

- De gebruikersvriendelijkheid van het systeem;

- De presentatie van diverse kaartlagen;

- Het inzichtelijk maken van de gehanteerde methoden om tot bepaling van de basiskwaliteit en de gerealiseerde kwaliteit te komen;

- De mogelijkheid om eigen gegevens te uploaden.

De verbetersuggesties voor de ontsluiting van de diverse gegevens waren:

- Mogelijkheid (directe aansluiting) om de beheergegevens zoals die in SCAN-Office aanwezig zijn te kunnen gebruiken;

- Mogelijkheid (directe aansluiting) om weidevogelgegevens van SOVON, FFVW, LandschappenNL te kunnen gebruiken;

- Zorgen voor up-to-date bestanden voor ontwatering, openheid, verstoring en zwaarte (biomassa) van het gewas;

- Mogelijkheid om deze 'centraal ontsloten' gegevens te kunnen aanpassen met eigen gegevens.

\subsection{Realisatie technische verbeteringen}

\section{Omzetting van Flash naar Ext JS 6.5}

Het rekendeel van de BoM webtool is omgezet van Flash naar Ext JS 6.5, een javascript library. Dit was noodzakelijk, omdat Flash vanwege veiligheidsissues niet meer wordt ondersteund en daarmee geen verdere ontwikkeling mogelijk is. Hierbij is tevens de indeling van de webtool verbeterd [Figuur 1], naar aanleiding van de verkregen feedback tijdens de werkplaatsbijeenkomsten. De webtool is als volgt te bereiken: http://bom-test.services.geodesk.nl/bom_test/ [gebruiker/ww].

\section{Toevoeging nieuwe kaarten}

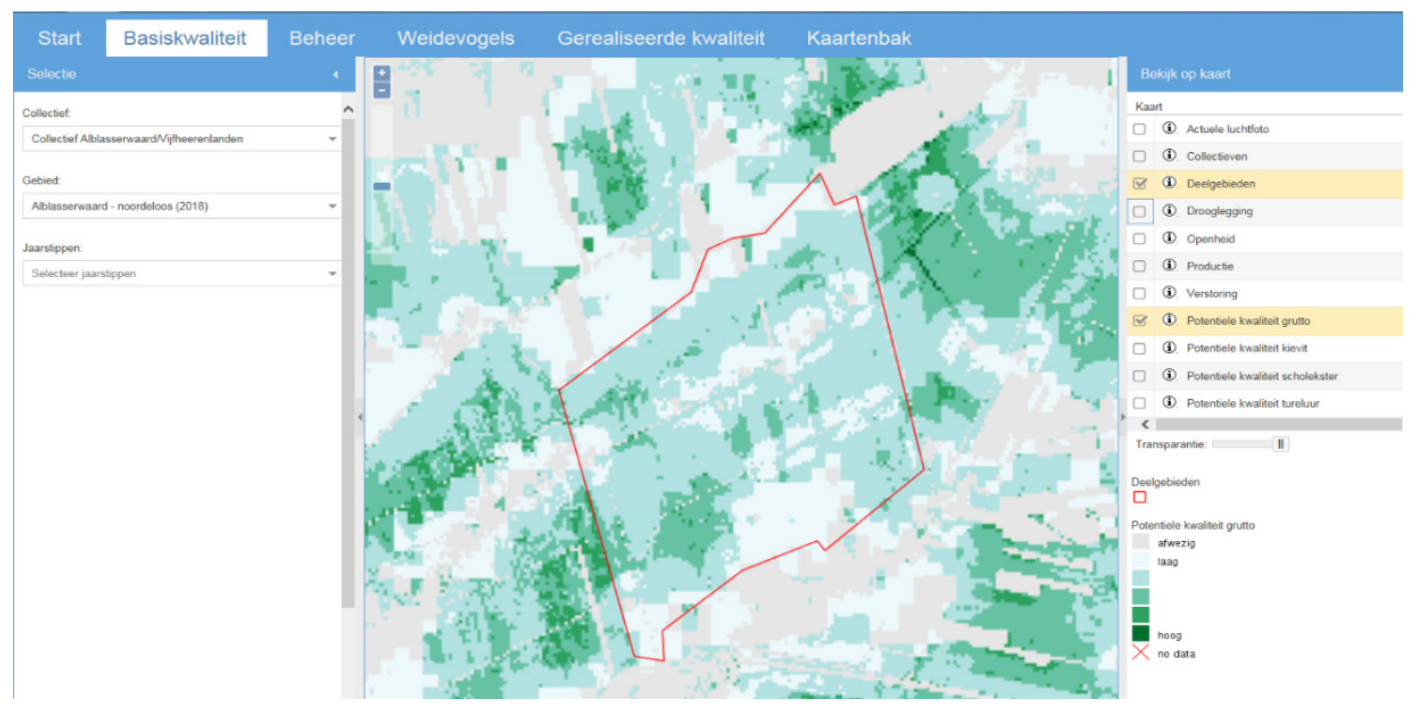

Figuur 1 Vernieuwde indeling Beheer op Maat-scherm

De kopjes aan de bovenzijde van de webpagina zijn zodanig ingedeeld dat de analyse stapsgewijs kan worden doorlopen van links naar rechts (zie Figuur $x$ ). Start = inloggen + gebied selecteren;

Basiskwaliteit = analyse landschappelijke kwaliteit; Beheer = analyse beheermozaïek (aansluiting,

verhouding zwaar/ licht beheer); Weidevogels = analyse weidevogeldichtheden en kerngebieden;

Gerealiseerde kwaliteit = analyse gerealiseerde habitatkwaliteit + foerageerhabitat voor

weidevogelkuikens; Kaartenbak = alle kaarten, zodat alle onderling gecombineerd kunnen worden (zie ook Figuur 3). 
Aan de bibliotheek zijn 9 kaartlagen toegevoegd, te weten: 1) 'bouwstenen-voor-kerngebieden grutto' (Figuur 2), 2) dichtheden grutto, 3) potentiële landschappelijke kwaliteit voor grutto, 4) tureluur, 5) kievit en 6) scholekster, 7) ligging reservaatbeheer, 8) begrenzing werkgebied collectieven, 9) begrenzing deelgebieden van collectieven.

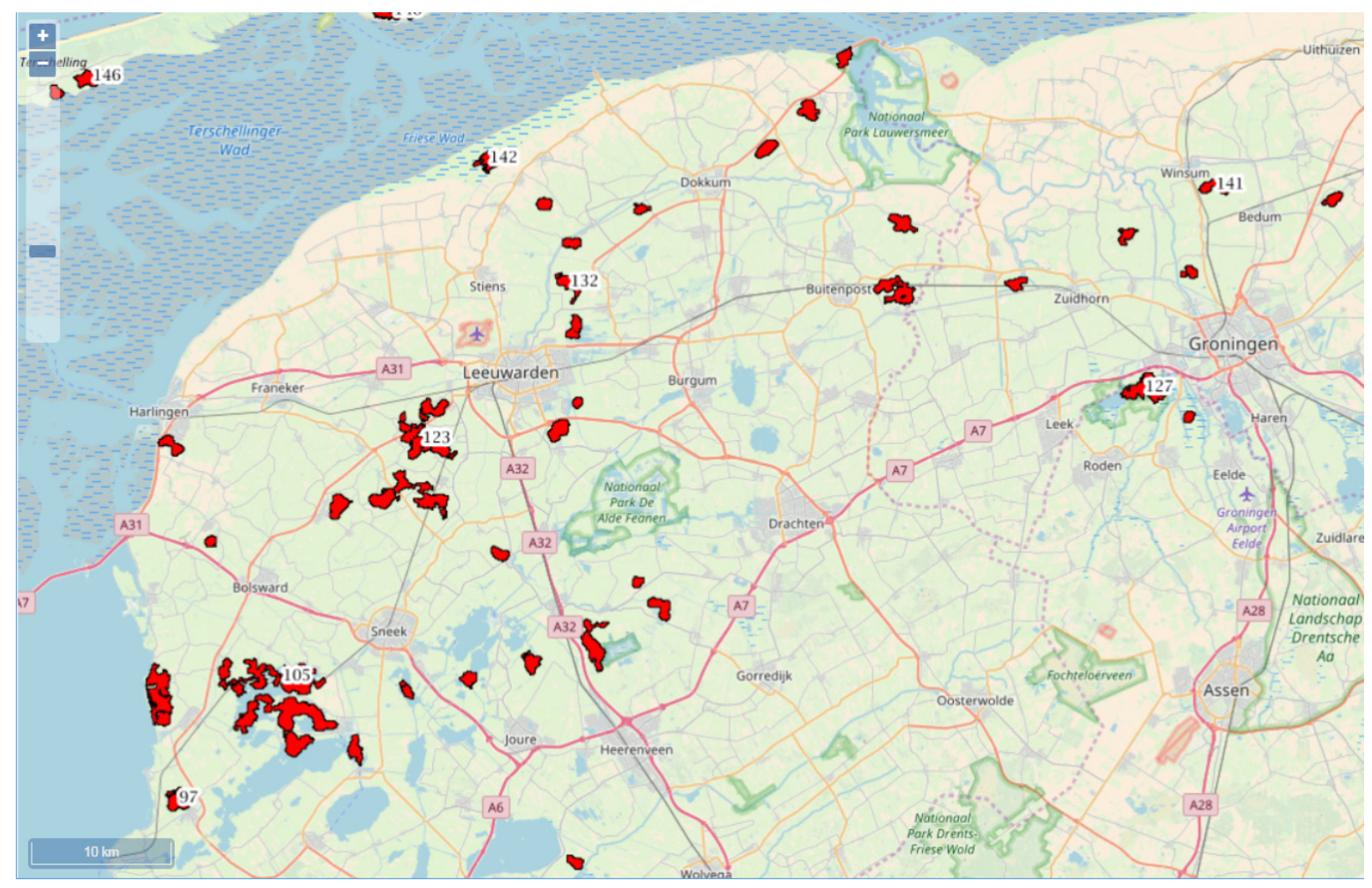

Figuur 2 Nieuw toegevoegde kaartlaag 'focal points kerngebieden grutto'. Deze kaartlaag toont 'bouwstenen-voor-kerngebieden' voor de grutto. Deze voldoen aan de volgende criteria:

- Ten minste 30 broedpaar grutto per 100 hectare.

- Suboptimale tot optimale omstandigheden ten aanzien van drooglegging, openheid, verstoring en zwaarte van het gewas (productiviteit).

- Ten minste 50 hectare aaneengesloten areaal dat aan de twee bovenstaande voorwaarden voldoet. Deze kaartvlakken (ca. 130 in heel Nederland) hebben een hoge actuele weidevogelkwaliteit en een relatief hoge basiskwaliteit en zijn voor een groot deel in beheer voor weidevogels. Ze vormen als het ware de 'focal points', de startpunten voor kerngebieden (op basis van Melman en Sierdsema, 2017).

\section{Mogelijkheid om combinatie van kaarten te bekijken}

De optie is toegevoegd om van de bovenliggende kaart de transparantie aan te passen. Daarmee ontstaat de mogelijkheid om kaarten gecombineerd te bekijken. Hierdoor kan de ligging van topografische elementen visueel worden verbonden aan een thematische kaart (bijv. openheid) en wordt oriëntatie gemakkelijker. Ook kan hiermee het verband tussen twee inhoudelijke kaartlagen visueel worden geanalyseerd (Figuur 3). 


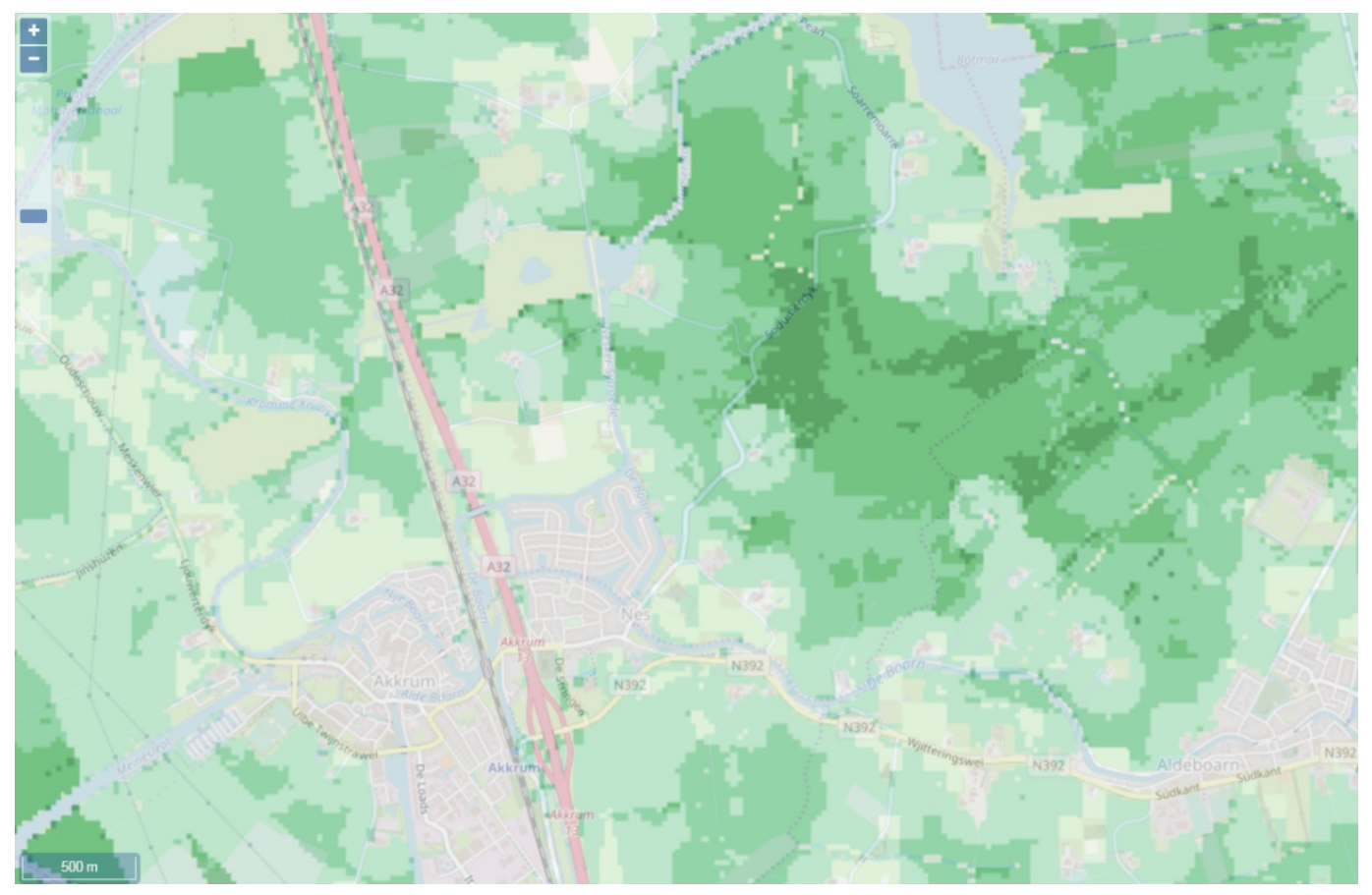

Figuur 3 Op dit kaartbeeld is de transparantie van de kaartlaag 'potentiële kwaliteit grutto' aangepast, waardoor de onderliggende topografische kaart zichtbaar is. Dit maakt het eenvoudiger een locatie op de kaart te herkennen. De transparantie van alle kaartlagen kan worden aangepast, zowel van inhoudelijke als referentielagen.

\section{Beknopte handleiding}

$\mathrm{Er}$ is een beknopte handleiding opgesteld en toegevoegd aan de webtool. De handleiding sluit aan op de vernieuwde indeling van de webapplicatie. De handleiding beschrijft op welke wijze de analyses kunnen worden uitgevoerd, hoe de resultaten kunnen worden geïnterpreteerd en welke rekenregels BoM toepast. Daarnaast wordt in de handleiding de achterliggende documentatie ontsloten (literatuurlijst + downloadlinks). De handleiding is toegevoegd als Bijlage 1 .

Met de realisatie van deze aanpassingen is invulling gegeven aan een groot deel van de wensen zoals die tijdens de werkplaatsen naar voren zijn gekomen.

\begin{tabular}{|c|c|}
\hline Wensen uit de werkplaatsen: verbetering ten aanzien van: & Gerealiseerd \\
\hline De gebruikersvriendelijkheid van het systeem & Ja \\
\hline De presentatie van diverse kaartlagen & $\mathrm{Ja}$ \\
\hline De mogelijkheid om eigen gegevens te uploaden & $\mathrm{Ja}$ \\
\hline
\end{tabular}

De overige wensen (zie par. 4.1) hebben betrekking op het netwerk waar BoM zou kunnen worden 'ingehangen', waardoor de gegevensbronnen die voor de berekeningen nodig zijn (beheer, wvinventarisaties e.d.) direct worden ontsloten. Het oppakken van deze wensen valt buiten de mogelijkheden/competenties van dit project. Dit vergt strategisch overleg met de verschillende bronhouders en betrokkenen en wordt een logische stap bij verdere verbreding van het gebruik van BoM.

\section{Kentallen om gebieden te karakteriseren}

Om gebieden te karakteriseren, is het handzaam om over een set aan kentallen te kunnen beschikken. Daarmee kunnen gebieden met elkaar worden vergeleken (benchmarking) of kan de ontwikkeling in de tijd worden verbeeld. In Bijlage 3 is een voorstel voor kentallen opgenomen. 


\section{$5 \quad$ Discussie}

Achterliggend doel van het project is de bruikbaarheid van het kennissysteem voor lerend beheer in het agrarisch natuurbeheer te vergroten. De door Hogeschool Van Hall Larenstein (HVHL) georganiseerde werkplaatsen boden daarvoor belangrijke input, als bron van gebruikerservaringen en verbeterwensen. Daarnaast is het kennissysteem en de benadering die daaraan ten grondslag ligt ook voor andere gelegenheden en in andere gremia gebruikt. Ook daar gaan we kort op in.

\section{Ervaringen tijdens de werkplaatsen}

Bedacht moet worden dat het om een eerste of hernieuwde kennismaking ging. Tijdens de werkplaatsen werd BoM door de collectieven in eerste instantie vooral getoetst aan de hand van het eigen, bekende werkgebied. In veel gevallen werden de knelpunten in habitatkwaliteit die BoM in beeld bracht door het collectief herkend. Door gebruik van het kennissysteem werden deze concreet getoond en daarmee voor collectieven bespreekbaar. Het ging bij de bespreking om zaken als de omvang en ernst van het knelpunten in de habitatkwaliteit en of verbetering wel/niet urgent was; hoe deze verbeteringen zouden kunnen worden gerealiseerd; wat de prioriteit van de aan te pakken verbetering was. Omdat BoM gebieden volgens eenduidige rekenregels en criteria analyseert, is de output goed te doorzien (één taal, één begrippenset) en kunnen gebieden met elkaar worden vergeleken. Hierdoor ontstonden als vanzelf discussies tussen de collectieven over de verschillen en overeenkomsten tussen gebieden, met vragen als: 'is drooglegging bij jullie ook het grootste probleem? Op welke wijze sluiten jullie aan op reservaatbeheer? Hebben jullie ook te maken met een beperkte openheid?'

De werkplaatsen hebben daarmee laten zien dat BoM in beginsel een waardevolle tool kan zijn voor lerend beheer. Nu zijn de werkplaatsen een incidenteel gebeuren geweest; voor lerend beheer zouden dergelijke sessies regelmatig moeten plaatsvinden. In welke vorm dat zou moeten en met welke frequentie zijn punten van nadere overweging. Het zou goed zijn als daaraan, naast collectieven, ook terreinbeheerders, onderzoekers en beleidsmakers deel zouden nemen. Daarmee komt er een meer gedeeld beeld over wat er nodig en mogelijk is om tot een effectief weidevogelbeheer te komen.

De ervaringen van voorjaar 2017 zijn voor HVHL en BNL aanleiding geweest om begin 2018 een tweede ronde werkplaatsen te organiseren. In deze ronde zal het accent liggen op het zelf gaan werken aan verbeterplannen ${ }^{5}$ in een of meerdere deelgebieden en vervolgens hierover onderling in discussie te gaan (benchmark). De in BoM aangebrachte verbeteringen kunnen dan op hun doelmatigheid worden beproefd en ongetwijfeld zullen nieuwe verbeterwensen naar boven komen. Deze werkplaatsen-tweede-ronde vormen de opmaat voor het project 'optimalisatieplannen agrarisch natuurbeheer' zoals dat door BoerennatuurNL is gestart en in 2017/18 zijn beslag krijgt. Belangrijke daarin genoemde aandachtspunten zijn de "herkenning van kansrijke gebieden aan de hand van de basiscondities die dat bepalen en de ruimtelijke samenhang en kwaliteit van het agrarisch natuurbeheer". Die wens geldt niet alleen voor 'open grasland' (weidevogels), maar ook voor de drie andere leefgebiedtypen ('open akker', 'droge dooradering', 'natte dooradering'). De ambitie van BoM is dergelijke informatie te bieden. In het BO-project van 2018 zal dit worden opgepakt.

\section{Status BoM}

BoM is gedurende een meerjaarsperiode stap voor stap ontwikkeld, als instrument om meer grip te krijgen op de kwaliteit van de plannen in het agrarisch natuurbeheer. Getracht is daarbij alle relevante wetenschappelijke kennis te benutten en om een breed draagvlak te krijgen bij alle betrokkenen van het agrarisch natuurbeheer. De verschillende rapporten die al die jaren zijn uitgebracht, geven aan dat dat een zoektocht is geweest. De fase waarin het agrarisch natuurbeheer zich nu bevindt, die van toenemende professionalisering van de collectieven en de toenemende maatschappelijke druk om tot

\footnotetext{
${ }^{5}$ Na de introductie van de regeling ANLb in 2016 wordt, mede naar aanleiding van de ex-ante-evaluatie uit 2016, nu hard gewerkt aan een verbeteringsslag van de beheerplannen.
} 
meer effectieve beheerpraktijk te komen, maakt dat BoM meer en meer als instrument voor lerend beheer herkend en erkend wordt. Het wordt daarmee ook steeds belangrijker dat de rekenregels die BoM bij de analyses gebruikt ook algemeen ondersteund worden.

Daarvoor lijkt het Deskundigenteam Cultuurlandschap van het OBN een belangrijk gremium te kunnen worden. Daarin zijn zowel beheerders, onderzoekers als beleidsmakers vertegenwoordigd. Zij hebben onder meer als taak ecologische kennishiaten te signaleren en bestaande kennis te verspreiden. Het agrarisch natuurbeheer neemt in deze groep op dit moment een centrale plek in. Het regelmatig tegen het licht houden van de rekenregels van BoM en daaraan adviezen te verbinden, zal het draagvlak van BoM en de acceptatie van de daarmee gegenereerde inzichten ten goede komen.

\section{Actualiteit en betrouwbaarheid van de gegevens; organisatie}

Uit de gebruikerservaringen komt naar voren dat de bruikbaarheid en relevantie van BoM sterk worden bepaald door de actualiteit en de betrouwbaarheid van de gegevens. Bij het gebruik van BoM moeten deze zaken dus op orde zijn. De verantwoordelijkheid hiervoor moet worden benoemd en bij een organisatie worden gelegd. Het ligt voor de hand BoerenNatuurNL hier een centrale rol te geven. Dat geldt zowel voor de gegevens voor de potentiële habitatkwaliteit (ontwatering, openheid, verstoring, zwaarte van het gewas), voor de gerealiseerde kwaliteit (het beheer) als voor de aanwezigheid en Bruto Territoriaal Succes (BTS) van weidevogelgezinnen. Voor weidevogels is al eerder een voorstel gedaan om te komen tot een zogenaamd Weidevogel Informatie Portaal (WIP); Teunissen et al. 2014).

\section{Aandacht voor validatie}

In het kennissysteem BoM wordt de bestaande kennis rond het agrarisch natuurbeheer gebundeld en in een geografische context ontsloten. Essentieel bij het gebruik van BoM is dat ook wordt getoetst of de inzichten zoals die in BoM naar voren komen, ook kloppen en voor de praktijk realistisch zijn: een validatie van BoM. In 2016 is daar een bescheiden begin mee gemaakt in het gebied van de Ronde Hoep (Melman et al. 2017), met als resultaat een stevige indicatie dat BoM realistische inzichten genereert: hoe hogere de door BoM berekende habitatkwaliteit, hoe groter de dichtheid aan gruttogezinnen. Ook in het greppelplas-drasonderzoek is de praktische bruikbaarheid van BoM gebleken (Visser et al. 2017). Deze validatie dient op grotere schaal te worden voortgezet (in andere gebieden). Uiteindelijke toets is vast te stellen of een hoge habitatkwaliteit samengaat met een grotere BTS. Aan de hand daarvan moeten er grenswaarden worden vastgesteld wanneer de habitatkwaliteit toereikend is voor een duurzame populatie. Ook op dit punt zal een traject van lerend beheer dienen te worden ingezet.

\section{BoM gedachtegoed voor scenario-aanpak weidevogels}

Afgelopen voorjaar is in opdracht van Min EZ, provincies, BNL, en VBN een aantal

weidevogelscenario's uitgewerkt (Melman en Sierdsema, 2017) en aan de Tweede Kamer aangeboden. Hierbij is gebruikgemaakt van het gedachtegoed zoals dat in BoM is ondergebracht. De essentie daarvan is de systematiek van het onderscheiden van de potentiële landschapskwaliteit (bepaald door openheid, drooglegging, verstoring en zwaarte van het gewas) en de realisatie van deze potentie door middel van het beheer (gerealiseerde kwaliteit). Aan deze kwaliteit kan een schatting van het aantal territoria worden verbonden. Deze benadering is handzaam gebleken om een aantal scenario's te onderscheiden, uiteenlopend in de zwaarte van de inspanningen (optimalisatie van alleen het beheer of van beheer én inrichting). De effecten op de weidevogels en de daarmee gemoeide kosten konden met elkaar worden vergeleken. De scenariostudie vormde het startpunt voor de verdere optimalisatie van het weidevogelbeheer op landelijke schaal.

\section{BoM als handvat voor reflectie van verbetering weidevogelplannen Zuid-Holland}

Afgelopen najaar is er in Zuid-Holland op verzoek van de provincie door de collectieven gewerkt aan een verbetering van de weidevogelplannen voor 2018. Omdat het in de praktijk niet eenvoudig is om tot een optimaal plan te komen, wil de provincie nadrukkelijk inzetten op een verbetertraject, een traject waarin lerend beheer een belangrijke rol speelt. Daartoe is een kennisteam opgericht. De provincie heeft daarbij belangstelling voor BoM. BoM is aantrekkelijk, omdat het alle relevante kennis ontsluit, gekoppeld aan topografie. Daarmee is de kennis voor de gebruikers gemakkelijk te duiden en zijn er handvaten om tot verbetering te komen. Inmiddels is met behulp van BoM voor alle plannen een reflectierapport opgesteld (Visser en Melman, 2017). Dit reflectierapport is input bij het overleg 
tussen de collectieven en het kennisteam: een gedeeld startpunt. Essentieel voor het proces is dat het reflectierapport niet als beoordeling wordt gelezen, maar als handvat om de kwaliteiten ven het gebied te kennen en gezamenlijk tot verbeterpunten te komen.

\section{Verbreding van BoM naar andere leefgebiedtypen}

In het nieuwe stelsel is er sprake van een verbreding van de aandacht van het agrarisch natuurbeheer naar de andere leefgebiedtypen: open akkers, droge dooradering en natte dooradering (zie ook Melman et al. 2016. In het komende jaar zal aan deze verbreding door de WUR aandacht worden geschonken. Meer dan voor weidevogels het geval was, zal voor deze nieuwe leefgebiedtypen aan kennisontwikkeling aandacht geschonken moeten worden (zie bijvoorbeeld:

http://www.natuurkennis.nl/landschappen/cultuurlandschap/cultuurlandschap/algemeencultuurlandschap/). 


\section{Conclusies en aanbevelingen}

- Het houden van werkplaatsen voor collectieven om gezamenlijk ervaring op te doen bij het gebruik van BoM heeft waardevolle informatie opgeleverd over sterke punten en verbeterpunten van het kennissysteem.

- De fase waarin het agrarisch natuurbeheer zich nu bevindt (toenemende professionalisering, groeiende behoefte om tot grotere ecologische effecten te komen), maakt dat een kennissysteem als BoM daarvoor een handzaam instrument kan worden.

- De bruikbaarheid van BoM zit hem met name in de context van lerend beheer en benchmarking. Het gebruik van één taal en één begrippenset en de topografie-gebonden ontsluiting van kennis zijn daarbij belangrijke dragers.

- De werkplaatsen hebben een aantal verbeterwensen opgeleverd die al voor een belangrijk deel gerealiseerd konden worden. Dit proces van ervaringen uitwisselen en verbeterpunten signaleren en prioriteren, zal de komende jaren verder gecontinueerd dienen te worden, wil BoM voor de collectieven verder uitgroeien als een praktisch hulpmiddel bij het agrarisch natuurbeheer.

- Bij het gebruik van BoM in de beheerpraktijk is de status ervan belangrijk: wordt het achterliggende gedachtegoed breed gedragen? Een organisatie zoals het deskundigenteam Cultuurlandschap van het OBN, waarin beheerders, onderzoekers en het beleid vertegenwoordigd zijn, zou hiervoor een gremium kunnen zijn.

- Bij het werken met BoM voor de praktijk is het gebruik kunnen maken van actuele en betrouwbare gegevens essentieel. Dit dient goed te worden geregeld. BoerenNatuurNL, als koepelorganisatie van de beheerders, zou hierin een sleutelrol kunnen vervullen.

- Essentieel bij het gebruik van BoM is dat wordt getoetst of de inzichten die het oplevert realistisch zijn. De inzichten dienen in de praktijk te worden gevalideerd. Ook op dit punt dient een traject van lerend beheer te worden ingegaan.

- Bij de verdere ontwikkeling van het agrarisch natuurbeheer is het moment aangebroken om de focus te gaan verbreden van het weidevogelbeheer naar het beheer van de andere leefgebiedtypen. Meer dan voor weidevogels het geval was, zal voor deze nieuwe leefgebiedtypen aandacht geschonken moeten worden aan kennisontwikkeling. 


\section{Literatuur}

Kleijn, D., Dimmers, W., van Kats, R., Melman, D. \& Schekkerman, H., 2007. De voedselsituatie voor gruttokuikens bij agrarisch mozaïekbeheer. Wageningen, Alterra, Alterra-rapport 1487.

Manhoudt, A. en I. Klein, 2017. Verslag werkplaatsen BoM. Interne notitie HVHL-Leeuwarden. (zie ook Bijlage 2).

${ }^{*}{ }^{6}$ Meeuwsen, H.A.M. \& R. Jochem, 2011. Openheid van het landschap; Berekeningen met het model Viewscape. Wageningen, Wettelijke Onderzoekstaken Natuur \& Milieu, WOt-werkdocument 281.

*Melman, D. M. Kiers, H. Meeuwsen, A. Schotman, H. Sierdsema, B. Vanmeulebrouk, P. Wiersma, 2009. Werkzaamheden weidevogelonderzoek BO-2008; voortgangsrapportage Beheer-op-Maat 2008: naar identificatie kerngebieden weidevogelbeheer. Wageningen, Alterra, Alterrarapport 1865 .

*Melman, Th.C.P., H. Sierdsema, R. Buij, G. Roerink, H. ten Holt, S. Martens, H.A.M. Meeuwsen, A.G.M Schotman, 2014. Uitwerking kerngebieden weidevogels; -peiling draagvlak bij provincies; verbreding kennissysteem BoM. Wageningen, Alterra Wageningen UR (University \& Research centre), Alterra-rapport 2564.

*Melman, Th.C.P., R. Buij, A.G.M. Schotman, C.C. Vos, R.C.M. Verdonschot, H. Sierdsema en B. Vanmeulebrouk, 2016. Kennissysteem agrarisch natuurbeheer; Ondersteuning voor lerend beheer in het agrarisch natuurbeheer. Wageningen, Alterra Wageningen UR (University \& Research centre), Alterra-rapport 2702.

Melman, Th.C.P., A.G.M. Schotman, H.A.M. Meeuwsen, R.A. Smidt, B. Vanmeulebrouk en H. Sierdsema, 2016. Ex-ante-evaluatie ANLb-2016 voor lerend beheer; Een eerste blik op de omvang en ruimtelijke kwaliteit van het beheer in het nieuwe stelsel. Wageningen, Wageningen Environmental Research, Rapport 2752.

Melman, Th.C.P., A.G.M. Schotman, B. Vanmeulebrouk, I. Staritsky, H.A.M. Meeuwsen, 2017. Kennissysteem agrarisch natuurbeheer: aandacht voor inpasbaarheid en validatie. Wageningen, Wageningen Environmental Research, Rapport 2791.

Melman, Th.C.P. \& H. Sierdsema, 2017. Weidevogelscenario's: Mogelijkheden voor aanpak van verbetering van de weidevogelstand in Nederland. Wageningen, Wageningen Environmental Research, Rapport 2796.

*Schotman, A.G.M., Th.C.P. Melman, H.A.M. Meeuwsen, M.A Kiers \& H. Kuipers, 2005. Naar een Grutto-mozaïekmodel; Definitie van een model voor evaluatie vooraf van de effectiviteit van mozaïekbeheer. Stand van zaken juni 2005. Wageningen, Alterra, Alterra-rapport 1199.

*Schotman, A.G.M., Th.C.P. Melman, 2006. Haalbaarheidsstudie nieuw weidevogelgebied. Wageningen, Alterra, Alterra-Rapport 1336.

*Schotman, A.G.M., M.A. Kiers \& Th.C.P. Melman, 2007. Onderbouwing grotto-geschiktheidskaart; Ten behoeve van Grutto-mozaïekmodel en voor identificatie van weidevogelgebieden in Nederland. Wageningen, Alterra, Alterra-rapport 1407.

*Schotman, A.G.M., Th.C.P. Melman, S.R. Hensen, M.A. Kiers, H.A.M. Meeuwsen, O.R. Roosenschoon \& B. Vanmeulebrouk, 2008. Het Grutto-mozaïekmodel als kwaliteitstoets weidevogelbeheer; ontwikkelingen en toepassingen 2004-2008. Wageningen, Alterra, Alterra-rapport 1408.

*Schotman, A.G.M., Th.C.P. Melman, J.H. Ringrose, H.A.M. Meeuwsen, B. Vanmeulebrouk, W. Nieuwenhuizen, 2015. Beheer op Maat, op weg naar lerend beheer voor weidevogels. Wageningen, Alterra Wageningen UR (University \& Research Center), Alterra-rapport 2643.

*Sierdsema, H., A.G.M. Schotman, E.B. Oosterveld en Th.C.P. Melman, 2013. Weidevogelkerngebieden Noord-Holland; vergelijking van vier scenario's. Wageningen, Alterra, Alterra-rapport 2435; Sovon-rapport 2013/23; A\&W-rapport 1899.

*Teunissen, W.A., A.G.M. Schotman, L.W. Bruinzeel, H. ten Holt, E.O. Oosterveld, H.H. Sierdsema, E. Wymenga en Th.C.P. Melman, 2012. Op naar kerngebieden voor weidevogels in Nederland. Werkdocument met randvoorwaarden en handreiking. Wageningen, Alterra, Alterra-rapport 2344.

${ }^{6}$ De met * aangeduide zijn publicaties die in de loop der tijd over BoM zijn verschenen en worden in de tekst niet aangehaald. 
Nijmegen, Sovon Vogelonderzoek Nederland, Sovon-rapport 2012/21, Feanwâlden, Altenburg \& Wymenga ecologisch onderzoek, A\&W- rapport 1799.

Teunissen, W., R. Foppen, Chr. van Turnhout \& R. Vogel, 2014. Naar een integratie van monitoringmethoden voor weidevogels. Sovon-rapport 2014/21.

Visser, T. en D. Melman, 2017. Reflectie verbeterplan weidevogelbeheer - acht plangebieden in $\mathrm{ZH}$ Interne notities t.b.v. Kennisteam Weidevogels van de provincie Zuid-Holland. WEnR, Wageningen UR.

Visser, T., Th.C.P. Melman, R. Buij en A.G.M. Schotman, 2017. Greppelplas-dras voor weidevogels; betekenis als habitatonderdeel voor weidevogelkuikens. Wageningen Environmental Research (Alterra). Rapport 2845. Wageningen UR. 


\section{Bijlage 1 Handleiding Beheer op Maat}

\section{Inleiding}

\section{Doel}

Deze handleiding heeft als doel de gebruiker van Beheer op Maat (BoM):

1. te ondersteunen bij het uitvoeren van analyses binnen de webapplicatie van BoM;

2. te ondersteunen bij het interpreteren van de kaartbeelden die BoM genereerd;

3. inzicht te bieden in de wijze waarop Beheer op Maat functioneert (rekenregels, rekenwaarden, algoritmes, etc.).

\section{Leeswijzer}

In hoofdstuk 1 wordt een aantal tips en aandachtspunten besproken die van pas kunnen komen wanneer men met Beheer op Maat aan de slag gaat. De volgorde van alle opvolgende hoofdstukken is gelijk aan de indeling zoals die wordt gehanteerd in de webapplicatie: in hoofdstuk 2 wordt besproken welke handelingen de gebruiker dient uit te voeren alvorens kan worden gestart met de inhoudelijke analyse. In hoofdstuk 3 wordt uitgelegd hoe de gebruiker de basiskwaliteit van het gebied kan analyseren. Vervolgens wordt in hoofdstuk 4 \& 5 duidelijk hoe het beheermozaïek en de ligging van de weidevogelterritoria kunnen worden geanalyseerd. Ten slotte beschrijft hoofdstuk 5 op welke wijze de gerealiseerde kwaliteit kan worden berekend. In dit hoofdstuk komen alle analyses uit voorgaande stappen samen en wordt duidelijk wat de huidige indeling van het beheer oplevert op het vlak van habitatkwaliteit voor weidevogels.

Enkele tekstonderdelen in deze handleiding hebben een andere achtergrondkleur. Deze kleur is gegeven aan tekstonderdelen die beschrijven op welke wijze BoM analyses uitvoert en welke rekenregels daarbij worden gebruikt. Deze passages zijn bedoeld voor de geïnteresseerde lezer. Ook zonder het lezen van deze passages kunnen de resultaten van de analyses worden geïnterpreteerd. 


\section{Tips \& Aandachtspunten}

\section{Referentiebeelden}

Binnen het kennissysteem is een aantal kaartlagen toegevoegd die handig kunnen zijn als referentiebeeld. Het gaat hierbij om de volgende kaartlagen:

- Actuele luchtfoto: Satellietbeeld 2017.

- Collectieven: Begrenzing werkgebieden collectieven.

- Deelgebieden: Begrenzing deelgebieden (o.b.v. zelf aangegeven grenzen tijdens werkbijeenkomsten in 2017).

\section{Transparantie van kaartlagen aanpassen}

Binnen het kennissysteem is het mogelijk om de transparantie van een kaartlaag aan te passen. Hierdoor kunnen twee kaartlagen over elkaar heen worden weergegeven. Deze functie kan voor twee doeleinden worden gebruikt:

1. Het verbeteren van de 'leesbaarheid' van een kaart door de toevoeging van een referentiekaart (zie hierboven).

2. Het visueel analyseren van de relatie tussen twee inhoudelijke kaartlagen (bijvoorbeeld de relatie tussen de kaartlagen 'Gerealiseerde habitatkwaliteit' en 'Jaarstippen').

\section{Werkwijze \& voorbeeld}

In onderstaand voorbeeld (Figuur 1 ) is de potentiële kwaliteit van gebied $X$ voor de grutto weergegeven. Aan de rechterzijde van de pagina is te zien dat slechts 1 kaartlaag is geactiveerd, namelijk 'potentiële kwaliteit grutto'.

In Figuur 2 is een satellietbeeld toegevoegd aan de weergave, wat het eenvoudiger maakt om de locatie van een deel van de kaart te achterhalen. De werkwijze voor het toevoegen van een referentielaag is als volgt:

- Vink een tweede kaart aan (in dit geval 'actuele luchtfoto', zie bovenste zwarte pijl in Figuur 2).

- Pas de transparantie van de kaartlaag die als $2^{\mathrm{e}}$ is geselecteerd* naar wens aan door de slider voor transparantie te verschuiven (zie onderste zwarte pijl in Figuur 2).

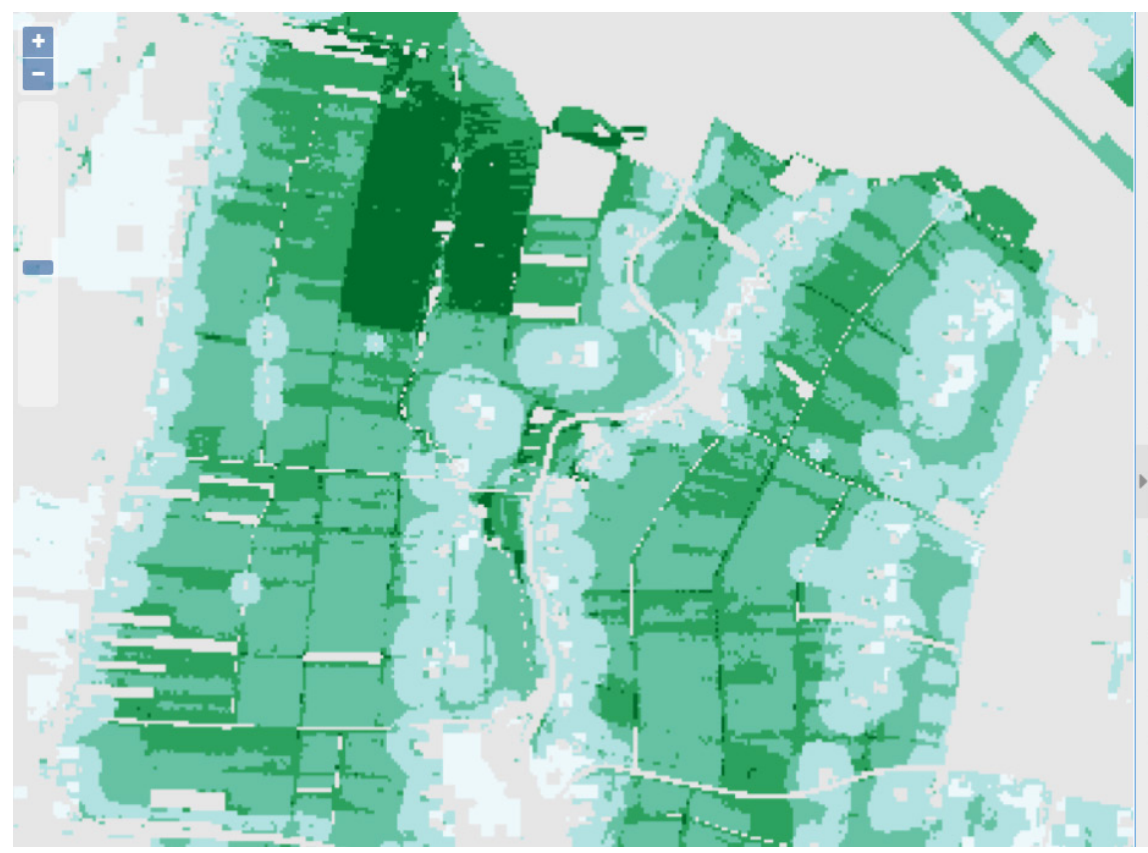

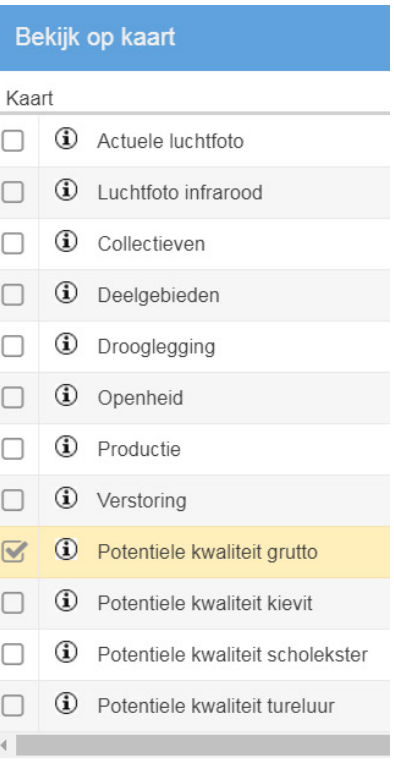

Transparantie:

Figuur 4 Weergave potentiële kwaliteit grutto ZONDER activering van een tweede, transparante kaartlaag. 


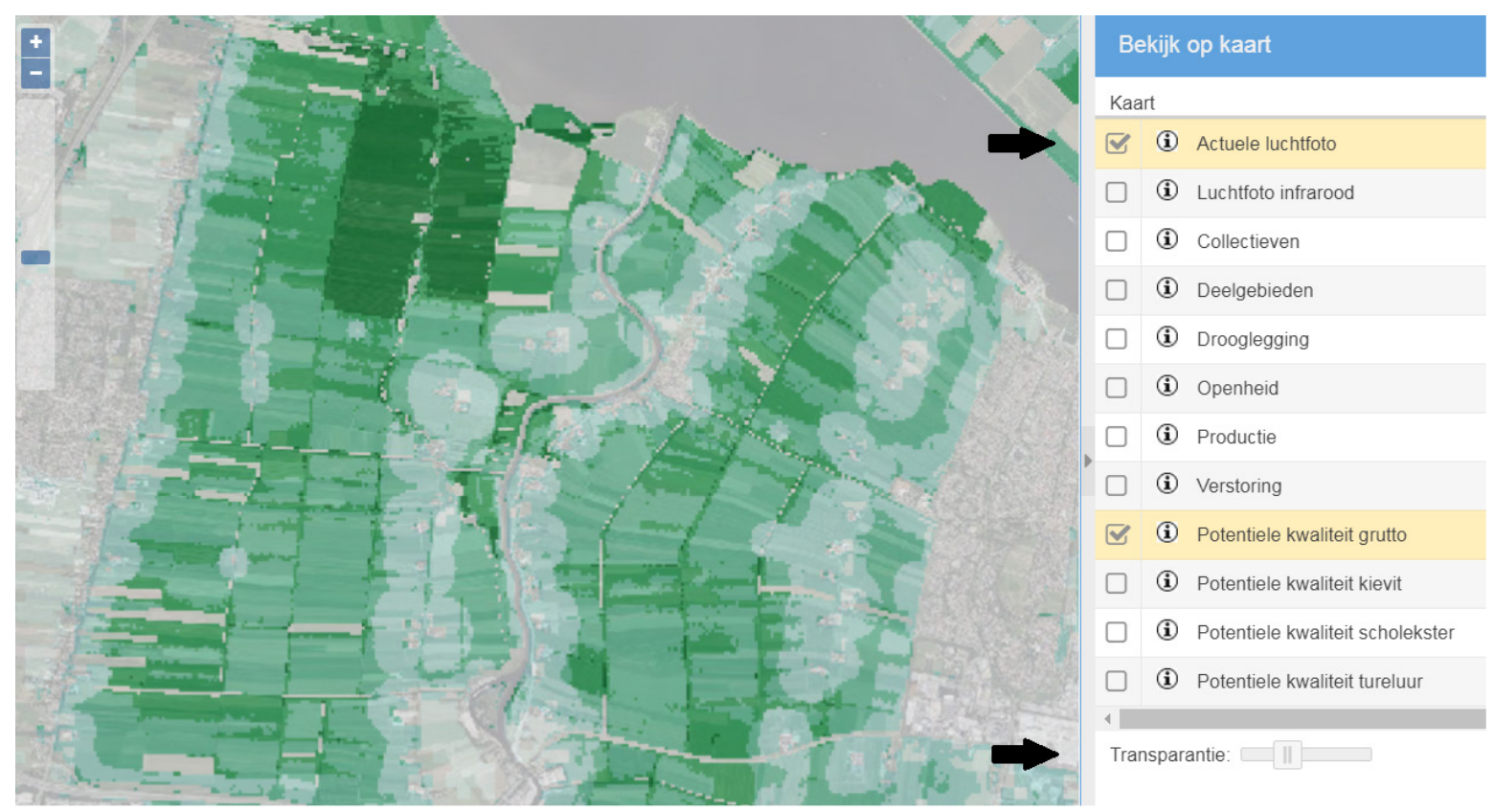

Figuur 5 Weergave potentiële kwaliteit grutto MET activering van een tweede, transparante kaartlaag.

\section{BoM: geen absolute waarheid}

Tijdens het werken met Beheer op Maat is het belangrijk om de resultaten van het kennissysteem niet te beschouwen als een absolute waarheid. BoM is bedoeld als handvat voor het analyseren van een weidevogelgebied en is gebaseerd op rekenregels die op landelijke schaal toepasbaar zijn. Het is aan de beheerder om bij het interpreteren van de kaartbeelden gebiedsspecifieke omstandigheden in acht te nemen. Voorbeeld: een bosje heeft op de kaart een verstorende werking. Mocht het bosje recentelijk zijn afgezet (wat de kaart nog 'niet weet'), dan zal de verstorende werking geringer zijn en kan de gebruiker de berekende verstoring negeren. 


\section{Start}

\section{Inloggen}

Allereerst dient de gebruiker in te loggen. Dit kan worden gedaan door op de knop 'login' te klikken (zie rechterkant, bovenzijde pagina). Gebruik voor het inloggen de gebruikersnaam en het wachtwoord die aan het collectief beschikbaar zijn gesteld.

\section{Selecteren werkgebied \& jaarstippen}

$\mathrm{Na}$ het inloggen kan aan de linkerzijde van de pagina het collectief en/of deelgebied worden geselecteerd waarin de gebruiker geïnteresseerd is. Van ieder deelgebied zijn meerdere versies beschikbaar. Ten eerste zijn er versies beschikbaar van verschillende jaren (= mogelijk verschillen in het beheermozaïek). Daarnaast zijn er een 'moederlaag' en 'speelversies' beschikbaar. Door de speellaag te selecteren, kan men in een later stadium van de analyse (hoofdstuk 3: beheer) het beheer aanpassen. Dit is niet mogelijk binnen de moederlaag.

Ten slotte kan op de startpagina worden gekozen welk jaarstippenbestand het kennissysteem dient te gebruiken bij de analyses (eigen gegevens of gegevens van andere partijen zoals SOVON). 
2.1 Drooglegging, openheid, verstoring, productie

\section{Definitie \& belang}

De basiskwaliteit of landschappelijke kwaliteit van een locatie wordt bepaald door vier factoren: drooglegging, openheid, verstoring en de productiviteit van het grasland. De definitie en het belang van deze factoren worden hieronder uitgelegd.

\section{Drooglegging}

Definitie: De drooglegging is het verschil tussen de hoogte van het maaiveld en de hoogte van het slootwaterpeil. Men spreekt van een geringe drooglegging wanneer het slootwaterpeil hoog staat ten opzichte van het maaiveld. Men spreekt van een grote drooglegging wanneer het slootwaterpeil laag staat ten opzichte van het maaiveld. Een geringe drooglegging leidt tot een vochtige bodem. Een grote drooglegging leidt tot een relatief droge bodem.

Belang: De drooglegging van het gebied is van belang voor weidevogels, omdat de bodemvochtigheid 1) de bereikbaarheid van voedsel voor bodemtastende adulte weidevogels beïnvloedt en 2) de gewasgroei van concurrentiekrachtige grassen remt, wat het ontstaan van doorwaadbare, kruiden- en structuurrijke vegetaties bevordert, die een geschikt foerageerhabitat voor weidevogelkuikens vormen.

\section{Openheid}

Definitie: De openheid van het landschap is de mate waarin zichtlijnen worden geblokkeerd door opgaande structuren. Bij aanwezigheid van weinig opgaande structuren zijn de zichtlijnen lang en spreekt men dus van een grote openheid. Bij aanwezigheid van veel opgaande structuren zijn de zichtlijnen kort en spreekt men van een gesloten landschap.

Belang: De openheid van een gebied is van belang voor weidevogels, omdat weidevogels een voorkeur hebben voor een open landschap. Dit omdat gesloten landschappen 1) worden geassocieerd met de aanwezigheid van predatoren en 2) een open landshap het eenvoudiger maakt om predatoren op afstand te zien aankomen.

\section{Verstoring}

Definitie: Er is sprake van verstoring wanneer een weidevogel zijn gedrag aanpast als gevolg van de aanwezigheid van de verstorende bron. Hierbij gaat het zowel om het opvliegen van vogels naar aanleiding van naderende recreanten (fiets- en wandelpaden) als om de invloed die opgaande structuren zoals bebouwing, bomen en hoogspanningsmasten hebben op de locatiekeuze voor een nest/territorium. De aanwezigheid van dergelijke opgaande structuren leidt tot een reductie in de dichtheid van nesten en territoria in de nabijheid van verstorende bronnen, omdat weidevogels deze opgaande structuren associëren met de aanwezigheid van predatoren.

Belang: De aanwezigheid van verstorende bronnen in een weidevogelgebied is belangrijk, omdat dit kan leiden tot een reductie van het aantal nesten ten opzichte van een situatie waarin verstorende elementen afwezig zijn. Vooral de grutto en tureluur mijden zones in de nabijheid van verstorende bronnen. De kievit en vooral de scholekster zijn hiervoor minder gevoelig.

\section{Productiviteit grasland}

Definitie: Bij een hoge productiviteit is sprake van een hoge opbrengst (in termen van biomassa) per hectare per jaar. Bij een lage productiviteit is sprake van een lage opbrengst (in termen van biomassa) per hectare per jaar. De productiviteit is o.a. afhankelijk van de voedselrijkdom (bemesting) en drooglegging.

Belang: De productiviteit van het grasland beïnvloedt de kans op het ontwikkelen/ontstaan van kruidenrijke graslanden. In hoogproductieve graslanden worden kruiden weggeconcurreerd door grassen. In laagproductieve graslanden kan met het juiste beheer een kruidenrijke, open en structuurrijke vegetatie ontstaan. 


\section{Werkwijze in BoM}

1. Navigeer naar de pagina 'Basiskwaliteit' (zie bovenzijde webpagina).

2. Activeer de kaartlagen 'drooglegging', 'openheid', 'verstoring' en 'productie' door deze aan de rechterzijde van de pagina aan te vinken. De legenda zal zich automatisch aanpassen na het selecteren van een kaartlaag.

\section{Mogelijkheden analyse}

Relevante analyses die op basis van visuele inspectie van de kaartlagen op deze pagina kunnen worden uitgevoerd, zijn onder andere:

1. Welke factoren vormen een knelpunt ten aanzien van de basiskwaliteit (te droog? gesloten landschap? veel verstoring? etc.)?

2. Zijn er mogelijkheden om aan deze knelpunten te werken (vernatten? verwijderen opgaande structuren? etc.)?

\section{Rekenwijze BoM}

\section{Drooglegging}

De drooglegging is berekend door de maaiveldhoogte (op basis van het Algemeen Hoogtebestand Nederland $(\mathrm{AHN})$ ) te vergelijken met het vigerende peilbesluit. Hierbij is gebruikgemaakt van het waterpeil in de winter, omdat uit onderzoek in Noord-Holland is gebleken (Schotman et al. 2008) dat de drooglegging in de winter een belangrijke relatie heeft met de trend van weidevogels en het voorkomen van natte en vochtige graslanden tijdens het broedseizoen. Bij de interpretatie van de kaartlaag 'drooglegging' is het van belang om in het achterhoofd te houden dat de berekende drooglegging mogelijk niet overeenkomt met de daadwerkelijke situatie, bijvoorbeeld wanneer er sprake is van onderbemaling. De klassegrenzen voor drooglegging en de daarbij horende rekenwaarden zijn weergegeven in Tabel 2.

\section{Openheid}

De openheid van het landschap is berekend met behulp van het Viewscape-model (Meeuwsen en Jochem, 2011). In dit model worden opgaande structuren zoals bomenrijen en bebouwing beschouwd als ondoorzichtbare elementen. Het model rekent voor 4,5 miljoen locaties in Nederland uit wat de zichtafstand is. Dit wordt gedaan door vanaf de locatie in kwestie zichtlijnen te trekken in alle richtingen (360 graden) (zie Figuur 3). De lengte van de zichtlijn is afhankelijk van de aanwezigheid van opgaande structuren. Daar waar opgaande structuren afwezig zijn, is de zichtlijn lang (tot maximaal $1500 \mathrm{~m}$ ). Daar waar opgaande structuren aanwezig zijn, is de zichtlijn korter. De openheid van de locatie kan uiteindelijk worden bepaald door de gemiddelde lengte van de zichtlijnen in alle richtingen te nemen.

De klassegrenzen voor de openheid en de daarbij horende rekenwaarden zijn weergegeven in Tabel 2.

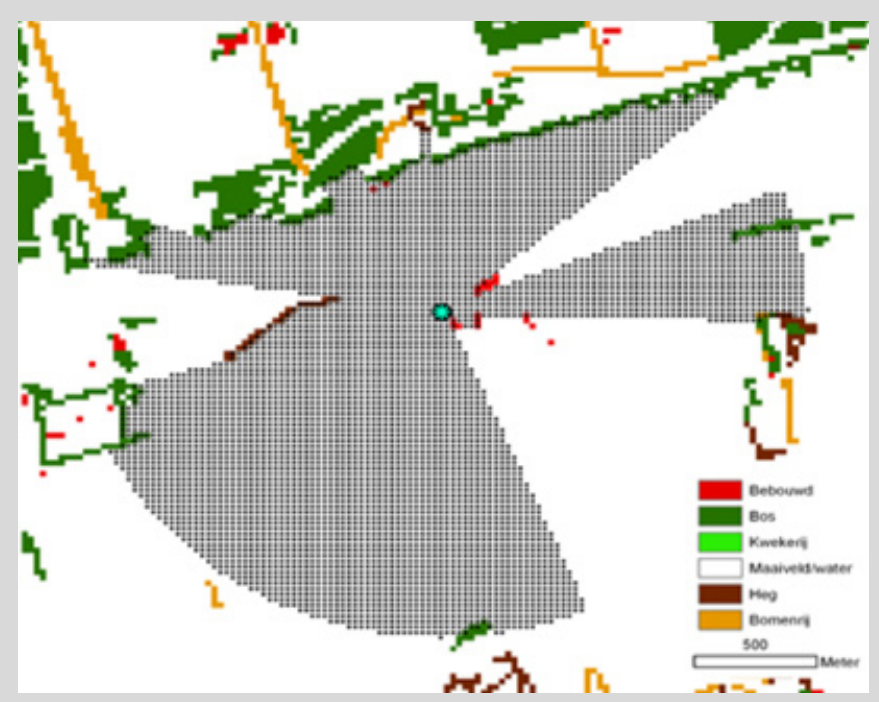

Figuur 6 Berekening openheid vanuit 1 vast punt. Grijze arcering toont de lengte van de zichtlijnen.

\section{Verstoring}

De verstorende bronnen zijn onderverdeeld in 3 categorieën, te weten 'riet', 'bomen' en 'nietverwijderbare bronnen' (bebouwing, hoogspanningsmasten, wegen etc.). Iedere categorie is gekoppeld aan een rekenwaarde tussen 0 en 1 , die aangeeft in welke mate verstoring optreedt. De klassegrenzen voor verstoring en de daarbij horende rekenwaarden zijn weergegeven in Tabel 2. 
Daarnaast heeft iedere bron van verstoring zijn eigen verstoringsafstand (= de afstand tot waar de bron een verstorend effect heeft). De verstoringsafstanden zijn weergegeven in Tabel 1. De ligging van verstorende bronnen is afgeleid van de topografische TOP10NL-kaart.

Tabel 1 De verstoringsafstand per bron. Voor onderbouwing van de verstoringsafstanden, zie: Teunissen et al. 2012; Sierdsema et al. 2013.

\begin{tabular}{ll} 
Bron & Verstoringsafstand \\
Gemeentelijke wegen & 50 \\
\hline Provinciale wegen (minus autowegen) & 100 \\
\hline Auto(snel)weg & 150 \\
\hline Spoorlijn & 100 \\
\hline Fietspad & 50 \\
\hline Hoogspanningsleiding & 100 \\
Bosjes, landschapsbeplanting & 200 \\
\hline Lijnvormige beplanting (heggen, boomrij) & 200 \\
\hline Bos (>0,5 ha) & 400 \\
\hline Huizen buiten bebouwde kom & 200 \\
\hline Bebouwde kom & 300 \\
\hline Rietland (vanaf 2,5 m) & 50 \\
\hline Windturbines & 200 \\
\hline Gaswinstation & 200 \\
\hline
\end{tabular}

\section{Productiviteit grasland}

De productiviteit van het grasland wordt bepaald op basis van een verhoudingsgetal voor de infraroodreflectie (de NDVI index: Normalized Difference Vegetation Index). Voor BoM wordt het driejarig gemiddelde uitgerekend van de gewastoestand in april. Dit omdat de gewastoestand in april het beste te gebruiken is om te voorspellen of tijdens het broedseizoen een kruidenrijk en open grasland kan ontstaan (Melman et al. 2017; Melman et al. 2014).

De klassegrenzen voor de productiviteit van het grasland en de daarbij horende rekenwaarden zijn weergegeven in Tabel 2. Zie voor meer informatie over de toepassing van de NDVI-index: Melman et al. 2017.

Tabel 2 Deze tabel geeft de klassegrenzen per factor (drooglegging, verstoring, productiviteit en openheid) weer. De rekenwaardes die aan deze klasseindeling zijn gekoppeld, worden per soort weergegeven ( $G=$ grutto, $T=$ tureluur, $K=$ kievit, $S=$ scholekster). De rekenwaarden liggen tussen de 0 en de 1. Hoe dichter bij de 1, hoe gunstiger de klasse voor de soort in kwestie. Voor meer informatie over de totstandkoming van de rekenwaardes en klassegrenzen, zie Melman et al. 2015 en Melman et al. 2012.

\begin{tabular}{|c|c|c|c|c|c|c|}
\hline \multicolumn{7}{|c|}{ Drooglegging } \\
\hline \multirow[t]{2}{*}{ Klasse } & \multirow[t]{2}{*}{ Klasseomschrijving } & \multirow[t]{2}{*}{ Klassegrenzen (cm t.o.v. maaiveld) } & \multicolumn{4}{|c|}{ Rekenwaarde per soort } \\
\hline & & & G & $\mathrm{T}$ & $\mathrm{K}$ & $\mathrm{S}$ \\
\hline 1 & Nat & $<35 \mathrm{~cm}$ onder maaiveld & 1 & 1 & 1 & 1 \\
\hline 2 & Vochtig & $35-50 \mathrm{~cm}$ onder maaiveld & 0.9 & 0.9 & 1 & 1 \\
\hline 3 & Droog & $>50 \mathrm{~cm}$ onder maaiveld & 0.7 & 0.75 & 0.75 & 0.75 \\
\hline x & Ontbrekend & - & 0.75 & 0.75 & 0.75 & 0.75 \\
\hline Klasse & Klasseomschrijving & & G & $\mathrm{T}$ & $\mathrm{K}$ & $\mathrm{S}$ \\
\hline 1 & Niet verstoord & & 1 & 1 & 1 & 1 \\
\hline 2 & Verstoord door riet & & 0.9 & 0.9 & 0.9 & 0.5 \\
\hline 3 & Verstoord door bomen & & 0.75 & 0.75 & 0.75 & 0.75 \\
\hline 4 & Niet verwijderbare bro & & 0.5 & 0.5 & 0.5 & 0.5 \\
\hline Klasse & Klasseomschrijving & $\begin{array}{l}\text { Klassegrenzen (gemiddeld aantal meters } \\
\text { 'zichtbare' openheid') }\end{array}$ & G & $\mathrm{T}$ & $\mathrm{K}$ & $\mathrm{S}$ \\
\hline 1 & Zeer open & $>600$ & 1 & 1 & 1 & 1 \\
\hline 2 & Open & $300-600$ & 0.9 & 0.9 & 0.9 & 0.9 \\
\hline 3 & Half open & $150-300$ & 0.75 & 0.75 & 0.75 & 0.75 \\
\hline 4 & Vrij besloten & $50-150$ & 0.25 & 0.25 & 0.75 & 0.75 \\
\hline 5 & Besloten & $<50$ & 0 & 0 & 0.75 & 0.75 \\
\hline $\mathrm{x}$ & Ontbrekend & - & 1 & 1 & 1 & 1 \\
\hline \multicolumn{7}{|c|}{ Productiviteit grasland } \\
\hline \multirow[t]{2}{*}{ Klasse } & \multirow[t]{2}{*}{ Klasseomschrijving } & \multirow[t]{2}{*}{ Klassegrenzen (NDVI) } & \multicolumn{4}{|c|}{ Rekenwaarde per soort } \\
\hline & & & G & $\mathrm{T}$ & $\mathrm{K}$ & $\mathrm{S}$ \\
\hline
\end{tabular}




\section{Definitie \& belang}

Definitie: De potentiële kwaliteit is de combinatie van drooglegging, openheid, verstoring en de voedselrijkdom van de bodem. In het geval alle vier de factoren op orde zijn, wordt een hoge potentiële kwaliteit toegeschreven aan de locatie in kwestie. Wanneer een of meerdere factoren niet optimaal zijn, neemt de potentiële kwaliteit van de locatie af.

Belang: De potentiële kwaliteit geeft aan in hoeverre de locatie in kwestie geschikt is voor weidevogelbeheer.

\section{Werkwijze in BoM}

1. Navigeer naar de pagina 'Basiskwaliteit' (zie bovenzijde webpagina).

2. Activeer de kaartlagen 'potentiële kwaliteit (soortnaam)' door deze aan de rechterzijde van de pagina aan te vinken. De legenda zal zich automatisch aanpassen na het selecteren van de kaartlaag.

Er zijn vier verschillende vormen van 'potentiële kwaliteit' kaarten beschikbaar; één voor iedere soort (grutto, kievit, tureluur, scholekster). De kaartlagen verschillen op subtiele wijze, omdat er andere rekenregels worden toegepast vanwege verschillen in ecologie.

\section{Mogelijkheden analyse}

Relevante analyses die op basis van visuele inspectie van de kaartlagen op deze pagina kunnen worden uitgevoerd, zijn onder andere:

1. Waar liggen de kansrijkste gebieden voor weidevogelbeheer?

2. Welke factoren zorgen ervoor dat andere delen van de polder minder geschikt zijn?

\section{Rekenwijze BoM}

Voor iedere cel van $625 \mathrm{~m} 2(25 \times 25 \mathrm{~m})$ wordt de potentiële kwaliteit als volgt uitgerekend:

1) Score per factor: De locatie in kwestie scoort op vlak van alle vier de factoren een bepaalde kwaliteitsklasse. Hierbij geldt dat klasse 1 de hoogst mogelijke kwaliteit is (optimaal) en de overige klassen gekoppeld zijn aan minder geschikte omstandigheden. De grenzen van de klassen zijn gebaseerd op onderzoek en expert judgement en zijn weergegeven in Tabel 2.

2) Van klasse naar rekenwaarde: Aan iedere klasse is een bepaalde rekenwaarde gekoppeld, die verschilt per soort. De rekenwaarden liggen tussen de 0 en de 1 . Hoe dichter bij de 1, hoe gunstiger de klasse voor de soort in kwestie. Zo is in Tabel 2 te zien dat klasse 1 op het vlak van drooglegging (= nat) voor de grutto zeer geschikt is en dus weegwaarde 1 heeft. Op het vlak van verstoring wordt klasse 4 (vrij besloten) voor de grutto en tureluur vertaalt naar een rekenwaarde van 0.25 en voor de scholekster en kievit naar een weegwaarde van 0.75 . Dit betekend dus dat de kievit en scholekster toleranter zijn voor een beperking van de openheid.

3) Vermenigvuldigen van weegwaardes: Om de basiskwaliteit te berekenen worden de weegwaardes van alle 4 de klassen met elkaar vermenigvuldigd.

\section{Rekenvoorbeeld}

We gaan de potentiële kwaliteit van locatie $X$ voor de grutto uitrekenen. De fictieve locatie ' $X$ ' scoort op het vlak van drooglegging klasse 1 (rekenwaarde $=1)$, openheid klasse 2 (rekenwaarde $=0.9$ ) verstoring klasse 1 (rekenwaarde $=1)$ en productiviteit klasse $2($ rekenwaarde $=0.9)$. Door de rekenwaarden met elkaar te vermenigvuldigen wordt duidelijk dat de potentiële kwaliteit van de locatie 0.81 is (zie Tabel 3).

Tabel 3 Uitrekenen potentiële kwaliteit locatie X, voor grutto. Rekenwaarden zijn afgeleid uit Tabel 2.

\begin{tabular}{lll} 
Factor & Score Locatie A (klasse) & Score locatie A (rekenwaarde) \\
Drooglegging & $1(<35 \mathrm{~cm}$ onder maaiveld) & 1 \\
\hline Openheid & 2 (open, zicht 300-600 meter) & 0.9 \\
Verstoring & 1 (niet verstoord) & 1 \\
\hline Productiviteit & 2 Gemiddeld productief & 0.9 \\
\hline Uitrekenen potentiële kwaliteit & & $1 * 0.9 * 1 * 0.9=0.81$ \\
\hline
\end{tabular}




\section{Beheer}

\section{Definitie \& belang}

Het kennissysteem Beheer op Maat onderscheidt 17 verschillende beheerpakketten. Dit is een vereenvoudigde classificering ten opzichte van de indeling die wordt gehanteerd bij Boerennatuur.nl, waar ruim 40 beheerpakketten worden onderscheiden (meer dan 100 variaties). ANLb-pakketten die sterk op elkaar lijken en resulteren in dezelfde habitatkwaliteit zijn in BoM samengevoegd, om de werkbaarheid van het kennissysteem te verbeteren.

\section{Werkwijze in Bom}

1. Navigeer naar de pagina 'Beheer' (bovenzijde pagina).

2. Activeer de kaartlaag 'beheer' en/of 'reservaten' aan de rechterzijde van de pagina.

\section{Aanpassen beheer}

Binnen Beheer op Maat zijn twee typen beheerkaarten beschikbaar (moederlaag en speellaag). Beide tonen de ligging van het beheer op basis van gegevens zoals aangeleverd door $\mathrm{X}$. Het verschil tussen beide lagen zit ' $m$ in de mogelijkheid om het beheer aan te passen. Het beheermozaïek in de moederlaag is vergrendeld en kan niet worden gewijzigd. Dit in tegenstelling tot het beheermozaïek in de speellaag, waar het beheer wel kan worden gewijzigd (op perceelniveau kunnen beheerpakketten worden toegeschreven/gewijzigd). Op deze manier is het mogelijk om 'conceptplannen' te analyseren: Wat zou het opleveren als we het beheermozaïek op wijze X zouden veranderen...?

Het beheer in de speellaag kan op relatief eenvoudige wijze worden aangepast. Werkwijze:

1. Navigeer naar de pagina 'beheer' (bovenzijde pagina).

2. Selecteer bij gebied (linkerzijde pagina) de speellaag.

3. Selecteer aan de linkerzijde van de pagina een beheertype.

4. Klik het perceel aan waarvan het beheer moet worden gewijzigd.

De gemaakte veranderingen hoeven niet handmatig te worden opgeslagen. Door de speellaag bij verdere analyses (gerealiseerde kwaliteit, hoofdstuk 4) te gebruiken, kan men analyseren wat het beheer in potentie oplevert.

\section{Mogelijkheden analyse}

Relevante analyses die op basis van visuele inspectie van de kaartlagen op deze pagina kunnen worden uitgevoerd, zijn onder andere:

1. Wat is de verhouding tussen zwaar en licht beheer?

2. Is het beheer van voldoende omvang?

3. Zijn er duidelijke kernen van zwaar beheer te onderscheiden?

4. Liggen de beheerpakketten voldoende aaneengesloten?

5. Vormen landschappelijke barrières een probleem voor weidevogelgezinnen die op zoek gaan naar geschikt foerageerhabitat (bijvoorbeeld van percelen met legselbeheer naar percelen met een zwaar beheerpakket)?

6. Sluit het beheer (goed) aan op reservaatbeheer?

7. Sluit het beheer aan op andere weidevogelgebieden?

8. Liggen de (zware) beheerpakketten op de juiste locatie (= zwaar beheer op locaties met een hoge basiskwaliteit, licht beheer op locaties met een lage basiskwaliteit)?

9. Zijn er locaties met een hoge basiskwaliteit die momenteel niet worden benut (= locaties met een hoge basiskwaliteit zonder beheer of met legselbeheer)?

\section{Voorbeelden}

Vraag 8: In Figuur 4 is te zien dat de zware beheerpakketten in dit geval niet gunstig zijn gelegen; ze liggen op een locatie met een zeer lage basiskwaliteit. Herpositionering van het beheer en/of het nemen van maatregelen om de basiskwaliteit te verbeteren, zal wellicht verstandig zijn. 


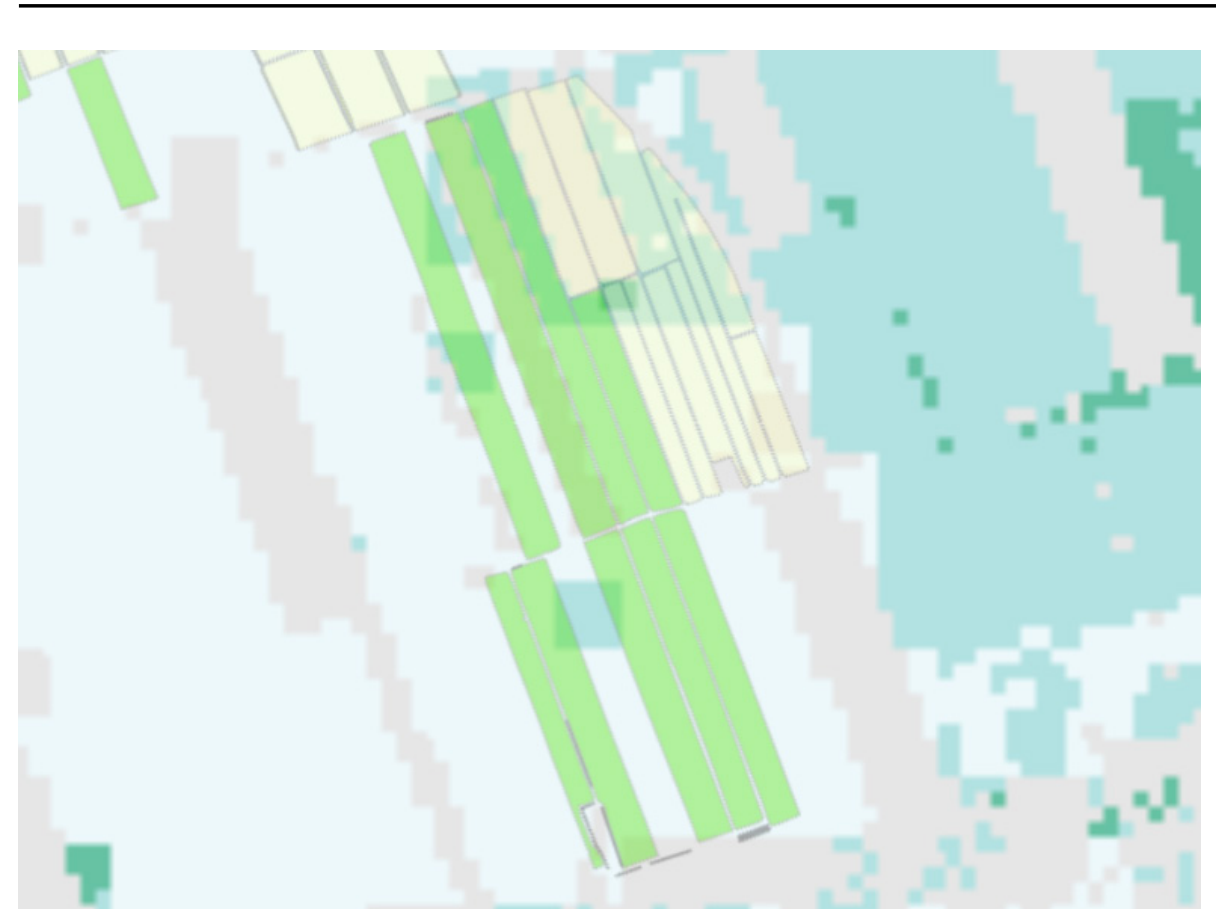

Figuur $7 \quad$ Ligging zware beheerpakketten(licht groene vlakken) t.o.v. potentiële kwaliteit (de ondergrond, herkenbaar aan het geblokte patroon) voor grutto.

Vraag 9: In Figuur 5 is te zien dat een aantal gebieden met een relatief hoge basiskwaliteit onbenut blijven. Deze gebieden zijn met zwarte lijnen omcirkeld. Als gebruiker kan men zich vervolgens de vraag stellen waarom deze locaties onbenut blijven. Komt dit door een gebrek aan bereidheid van de agrariër in kwestie? Heeft de gebruiker/het collectief een ander beeld van 'wat geschikte locaties zijn'? etc.

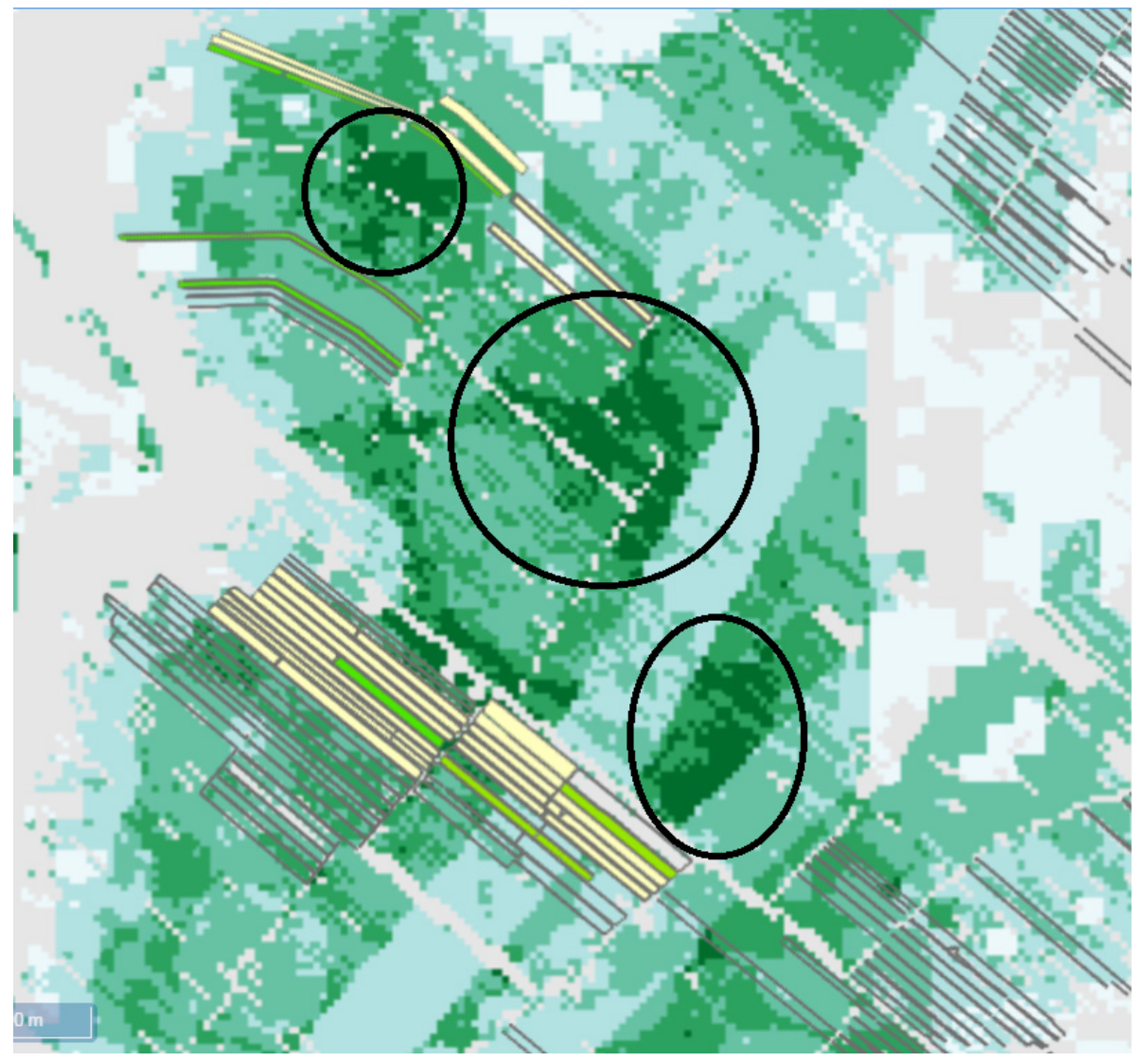

Figuur $8 \quad$ Locaties (zware cirkels) met een hoge potentiële kwaliteit die momenteel niet worden benut (= geen beheer). 


\section{Weidevogels}

\section{Definitie \& belang}

Op de pagina 'weidevogels' is een aantal kaartlagen die inzicht bieden in de verspreiding van weidevogels in het werkgebied. Er is een drietal kaartlagen beschikbaar:

\section{(Bouwstenen voor) Grutto-kerngebieden}

Deze kaartlaag toont kerngebieden voor de grutto. Deze kerngebieden voldoen aan de volgende criteria:

- Ten minste 30 broedpaar grutto per 100 hectare.

- Suboptimale tot optimale omstandigheden op het vlak van basiskwaliteit (klasse 1 of 2 voor alle factoren (drooglegging, openheid, verstoring, productiviteit)).

- Ten minste 50 hectare aaneengesloten areaal dat aan de twee bovenstaande voorwaarden voldoet (op basis van beschikbare gegevens zoals gebruikt door Melman en Sierdsema, 2017).

Deze kaartvlakken (ca. 130 in heel Nederland) hebben een hoge actuele weidevogelkwaliteit en een relatief hoge basiskwaliteit en zijn voor een groot deel al in beheer. Ze vormen als het ware het 'laaghangend fruit' om in kerngebieden op te nemen.

Gruttoklassen_aantal_per_250 m-cel

Dit kaartbeeld toont de dichtheid van gruttoterritoria. De dichtheden zijn vastgesteld op basis van monitoringsgegevens. Daar waar deze ontbreken, gaat het om gemodelleerde dichtheden op basis van omgevingsfactoren.

\section{Nesten/Territoria weidevogels}

Deze kaartlaag toont de ligging van weidevogel- territoria en nesten, zoals geïnventariseerd door het collectief.

\section{Werkwijze in Bom}

1. Navigeer naar de pagina 'Weidevogels' (bovenzijde pagina).

2. Activeer de kaartlaag 'Nesten/territoria weidevogel', 'Grutto_kerngebieden' of grutto_klassen_aantal_per_250m_cel' aan de rechterzijde van de pagina.

\section{Mogelijkheden analyse}

Relevante analyses die op basis van visuele inspectie van de kaartlagen op deze pagina kunnen worden uitgevoerd, zijn onder andere:

1. Ligt er een kerngebied voor de grutto in het werkgebied?

2. Zijn er duidelijke kernen van weidevogelterritoria te onderscheiden?

3. Zijn de nesten gunstig gelegen t.o.v. de zware beheerpakketten? 


\section{Gerealiseerde kwaliteit}

\section{$5.1 \quad$ Gerealiseerde habitatkwaliteit}

\section{Definitie \& belang}

Definitie: De gerealiseerde kwaliteit is de habitatkwaliteit die met behulp van het beheer wordt gerealiseerd. De gerealiseerde kwaliteit wordt beïnvloed door het type beheer en de basiskwaliteit. Hierbij is een aantal combinaties denkbaar:

- Hoge basiskwaliteit + zwaar beheer $\rightarrow$ hoge gerealiseerde habitatkwaliteit

- Hoge basiskwaliteit + licht beheer $\rightarrow$ lage gerealiseerde habitatkwaliteit

- Lage basiskwaliteit + zwaar/licht beheer $\rightarrow$ lage gerealiseerde habitatkwaliteit

Uit bovenstaande voorbeelden kan worden opgemaakt dat een hoge basiskwaliteit niet altijd leidt tot een hoge gerealiseerde kwaliteit. Het beheer bepaalt uiteindelijk wat er van de potentiële kwaliteit terechtkomt: uitsluitend wanneer een locatie met een hoge potentiële kwaliteit optimaal wordt benut (zwaar beheer), kan een hoge gerealiseerde kwaliteit worden gerealiseerd. Tevens kan uit bovenstaande voorbeelden worden opgemaakt dat zwaar beheer niet altijd leidt tot een hoge gerealiseerde kwaliteit; in het geval dat het zware beheer is gelegen op locaties met een lage basiskwaliteit, is de gerealiseerde kwaliteit ook laag.

Belang: Het analyseren van de gerealiseerde kwaliteit biedt inzicht in wat het weidevogelbeheer daadwerkelijk oplevert aan habitatkwaliteit. Of het beheer erin slaagt om een hoge gerealiseerde habitatkwaliteit te realiseren, is afhankelijk van - zoals kan worden opgemaakt uit bovenstaande alinea - de basiskwaliteit van het gebied en de ligging van het beheer.

\section{Werkwijze in BoM}

1. Navigeer naar de pagina 'Gerealiseerde kwaliteit' (bovenzijde pagina).

2. Selecteer aan de linkerzijde van de pagina het collectief, het deelgebied en het jaarstippenbestand die moeten worden gebruikt voor de analyse.

3. Selecteer aan de linkerzijde van de pagina de soort en de periode waarvoor de analyse dient te worden uitgevoerd. Als standaard worden de grutto en periode 2 geselecteerd. Dit omdat de grutto de meest kritische soort is en periode 2 (de $2^{\mathrm{e}}$ helft van mei) wordt beschouwd als de kritieke fase voor de kuikenoverleving.

4. Klik aan de linkerzijde van de pagina op de knop >>Rekenen $>>$ en wacht tot de berekening is uitgevoerd.

5. De resultaten van de analyse kunnen nu worden weergegeven door aan de rechterzijde van de pagina de kaartlaag 'gerealiseerde habitatkwaliteit' in te schakelen.

\section{Mogelijkheden analyse}

Relevante analyses die op basis van visuele inspectie van de kaartlagen op deze pagina kunnen worden uitgevoerd, zijn onder andere:

1. Tot welke gerealiseerde kwaliteit leidt het beheer?

2. Bij een gebrek aan gebieden met een hoge gerealiseerde kwaliteit $\rightarrow$ wordt dit veroorzaakt door de ligging van het beheer of door een lage potentiële kwaliteit? 


\section{Rekenwijze in BoM}

De wijze van berekenen is grotendeels gelijk aan de rekenwijze die wordt gebruikt voor het berekenen van de basiskwaliteit (zie hoofdstuk 2.1). Bij het berekenen van de gerealiseerde kwaliteit wordt echter het beheer als extra rekenwaarde aan de formule toegevoegd.

Aan ieder beheertype is een rekenwaarde gekoppeld, die aangeeft wat de waarde van het beheertype is als foerageerhabitat voor weidevogelgezinnen. Deze rekenwaarde ligt tussen de 0 en 1 . Hierbij geldt dat rekenwaarde 1 indiceert dat het beheertype zeer waardevol is voor de soort in kwestie en dat rekenwaarde 0 indiceert dat het beheertype geen waarde heeft voor de soort in kwestie. De rekenwaarden die aan de verschillende beheertypen zijn toegeschreven (zie Tabel 5), zijn gebaseerd op expert judgement. De verschillen in rekenwaarden voor de soorten worden veroorzaakt door verschillen in de ecologie van die soorten. Zo is bijvoorbeeld de optimale gewashoogte hoger voor de grutto dan voor de kievit.

\section{Rekenvoorbeeld}

We gaan de gerealiseerde kwaliteit van locatie $X$ voor de scholekster uitrekenen. De fictieve locatie ' $X$ ' scoort op het vlak van drooglegging klasse 1 (rekenwaarde $=1$ ), openheid klasse 2 (rekenwaarde $=0.9$ ) verstoring klasse 1 (rekenwaarde $=1$ ) en productiviteit klasse 2 (rekenwaarde $=1$ ). Door hier het beheer aan toe te voegen (in dit geval botanisch grasland in periode $2 \rightarrow$ rekenwaarde $=0.5$ ) en vervolgens de rekenwaarden met elkaar te vermenigvuldigen, wordt duidelijk dat de gerealiseerde kwaliteit van locatie $X$ 0.45 is (zie Tabel 4 ).

Tabel 4 Uitrekenen gerealiseerde kwaliteit van locatie $X$ voor scholekster, periode 2 ( ${ }^{e}$ helft van mei).

\begin{tabular}{lll}
\hline Factor & Score Locatie A (klasse) & Score locatie A (rekenwaarde) \\
Drooglegging & $1(<35 \mathrm{~cm}$ onder maaiveld) & 1 \\
\hline Openheid & 2 (open, zicht 300-600 meter) & 0.9 \\
\hline Verstoring & 1 (niet verstoord) & 1 \\
\hline Productiviteit & 2 Gemiddeld productief & 1 \\
\hline Beheer & Botanisch grasland, periode 2 & 0.5 \\
\hline Berekening potentiële kwaliteit & & $1 * 0.9 * 1 * 1 * 0.5=0.45$
\end{tabular}

Tabel 5 Deze tabel geeft van elk beheertype aan welke rekenwaarde wordt gebruikt (per soort \& per periode) voor het berekenen van de gerealiseerde kwaliteit. Voor meer informatie over de bepaling van de rekenwaarden, zie Schotman et al. 2008; Melman et al. 2009.

\begin{tabular}{|c|c|c|c|c|c|}
\hline \multirow[t]{2}{*}{$\#$} & \multirow[t]{2}{*}{ Beheerpakket } & \multirow[t]{2}{*}{ Soort } & \multicolumn{3}{|c|}{ Rekenwaarde per periode } \\
\hline & & & 1 & 2 & 3 \\
\hline \multirow[t]{3}{*}{1} & \multirow[t]{3}{*}{ Botanisch grasland } & G & 1 & 1 & 1 \\
\hline & & $\mathrm{K}$ & 1 & 1 & 1 \\
\hline & & $\mathrm{S}$ & 0.5 & 0.5 & 0.5 \\
\hline \multirow[t]{3}{*}{2} & \multirow[t]{3}{*}{ Uitgesteld maaien (>15 juni) } & G & 1 & 1 & 1 \\
\hline & & $\mathrm{K}$ & 1 & 1 & 0.5 \\
\hline & & $\mathrm{S}$ & 1 & 1 & 1 \\
\hline \multirow[t]{3}{*}{3} & \multirow[t]{3}{*}{ Uitgesteld maaien (<15 juni) } & G & 1 & 1 & 1 \\
\hline & & $\mathrm{T}$ & 1 & 1 & 1 \\
\hline & & $\mathrm{K}$ & 1 & 0.5 & 0.75 \\
\hline \multirow{2}{*}{4} & \multirow{2}{*}{ Extensief begraasd } & $\mathrm{K}$ & 1 & 1 & 1 \\
\hline & & $\mathrm{S}$ & 1 & 1 & 1 \\
\hline \multirow[t]{4}{*}{5} & \multirow[t]{4}{*}{ Plas-dras } & G & 1 & 1 & 1 \\
\hline & & $\mathrm{T}$ & 1 & 1 & 1 \\
\hline & & $\mathrm{K}$ & 1 & 1 & 1 \\
\hline & & $\mathrm{S}$ & 1 & 1 & 1 \\
\hline \multirow[t]{4}{*}{6} & \multirow[t]{4}{*}{ Gangbaar onderdeel mozaïek } & G & 1 & 1 & 1 \\
\hline & & $\mathrm{T}$ & 1 & 1 & 1 \\
\hline & & $\mathrm{K}$ & 0.75 & 0.75 & 0.75 \\
\hline & & $\mathrm{S}$ & 0.75 & 0.75 & 0.75 \\
\hline
\end{tabular}




\begin{tabular}{|c|c|c|c|c|c|}
\hline \multirow[t]{4}{*}{8} & Overig grasland & G & 0 & 0 & 0 \\
\hline & & $T$ & 0 & 0 & 0 \\
\hline & & $\mathrm{K}$ & 0.1 & 0.1 & 0.1 \\
\hline & & $\mathrm{s}$ & 0.1 & 0.1 & 0.1 \\
\hline \multirow[t]{4}{*}{9} & Bouwland braak & G & 1 & 0.5 & 0 \\
\hline & & $T$ & 1 & 0.5 & 0 \\
\hline & & $\mathrm{K}$ & 1 & 0.5 & 0 \\
\hline & & $\mathrm{S}$ & 1 & 0.5 & 0 \\
\hline \multirow[t]{4}{*}{10} & Akkerpakket & G & 0 & 0 & 0 \\
\hline & & $T$ & 0 & 0 & 0 \\
\hline & & $\mathrm{K}$ & 0.5 & 0.5 & 0.25 \\
\hline & & s & 0.75 & 0.75 & 0.5 \\
\hline \multirow[t]{4}{*}{11} & Laat zomergewas & G & 0 & 0 & 0 \\
\hline & & $T$ & 0 & 0 & 0 \\
\hline & & $\mathrm{K}$ & 0.75 & 0.5 & 0.25 \\
\hline & & $\mathrm{s}$ & 1 & 1 & 0.5 \\
\hline \multirow[t]{4}{*}{12} & Vroeg zomergewas & G & 0 & 0 & 0 \\
\hline & & $T$ & 0 & 0 & 0 \\
\hline & & $\mathrm{K}$ & 0.5 & 0.25 & 0 \\
\hline & & $\mathrm{s}$ & 1 & 0.50 & 0.25 \\
\hline \multirow[t]{4}{*}{13} & Overig bouwland & G & 0 & 0 & 0 \\
\hline & & $T$ & 0 & 0 & 0 \\
\hline & & $\mathrm{K}$ & 0 & 0 & 0 \\
\hline & & $\mathrm{s}$ & 0 & 0 & 0 \\
\hline \multirow[t]{4}{*}{14} & Reservaat overig & G & 1 & 1 & 1 \\
\hline & & $T$ & 1 & 1 & 1 \\
\hline & & $\mathrm{K}$ & 1 & 1 & 1 \\
\hline & & $S$ & 0.5 & 0.5 & 0.5 \\
\hline \multirow[t]{4}{*}{15} & Reservaat weidevogels & G & 1 & 1 & 1 \\
\hline & & $T$ & 1 & 1 & 1 \\
\hline & & $\mathrm{K}$ & 1 & 1 & 0.5 \\
\hline & & $S$ & 1 & 1 & 1 \\
\hline
\end{tabular}

\subsection{Omvang foerageerhabitat per weidevogelgezin}

\section{Definitie \& belang}

Definitie: De hoeveelheid foerageerhabitat die beschikbaar is per weidevogelgezin, rekening houdend met de waarde van verschillende typen graslanden en onderlinge concurrentie (territoria claims).

Belang: Deze analyse biedt inzicht in de hoeveelheid foerageerhabitat die beschikbaar is per weidevogelgezin. De hoeveelheid foerageerhabitat is van groot belang, omdat deze de overlevingskans van de weidevogelkuikens beïnvloedt. In de literatuur wordt als vuistregel gehanteerd dat ten minste 1 hectare foerageerhabitat per weidevogelgezin beschikbaar moet zijn (grutto).

\section{Werkwijze in BoM}

1. Navigeer naar de pagina 'Gerealiseerde kwaliteit' (bovenzijde pagina).

2. Selecteer aan de linkerzijde van de pagina het collectief, het deelgebied en het jaarstippenbestand die moeten worden gebruikt voor de analyse.

3. Selecteer aan de linkerzijde van de pagina de soort en de periode waarvoor de analyse dient te worden uitgevoerd. Als standaard worden de grutto en periode 2 geselecteerd. Dit omdat de grutto de meest kritische soort is en periode 2 (de $2^{\mathrm{e}}$ helft van mei) wordt beschouwd als de kritieke fase voor de kuikenoverleving.

4. Klik aan de linkerzijde van de pagina op de knop >>Rekenen >> en wacht tot de berekening is uitgevoerd.

5. De resultaten van de analyse kunnen nu worden weergegeven door aan de rechterzijde van de pagina de kaartlaag 'foerageerhabitat per weidevogelgezin' in te schakelen.

\section{Mogelijkheden analyse}

Relevante analyses die op basis van visuele inspectie van de kaartlagen op deze pagina kunnen worden uitgevoerd, zijn onder andere:

1. Hebben de weidevogelgezinnen beschikking over voldoende kuikenland?

2. Passen de resultaten van de analyse bij de BTS-gegevens?

3. Op welke plekken zou meer kuikenland moeten worden aangeboden? 


\section{Rekenwijze BoM}

Uitgangspunt: is er binnen de actieradius van een stip (weidevogelgezin), 1 ha van een gerealiseerde kwaliteit = 1 aanwezig die niet met andere weidevogelgezinnen hoeft te worden gedeeld, dan is de beschikbare hoeveelheid kuikenland ook 1 ha. Bij een lagere kwaliteit dan 1 is voor 1 ha kuikenland een grotere graslandoppervlakte nodig. Alleen kuikenland dat binnen de actieradius van een stip ligt, telt mee als beschikbaar kuikenland. Kuikenland buiten bereik van stippen (weidevogelgezinnen) telt niet mee (Melman et al. 2015).

Bom rekent de beschikbaarheid van foerageerhabitat voor weidevogelkuikens als volgt:

1) Identificeren ligging territoriastippen: De ligging van de territoriastippen wordt afgeleid van de aangeleverde monitoringsgegevens.

2) Tekenen actieradius: Rondom iedere territoriastip wordt de actieradius getekend. Alle cellen van 25 bij $25 \mathrm{~m}$ die binnen deze radius vallen, worden als bereikbaar bestempeld en vormen dus 'bereikbaar foerageerhabitat'. De grootte van de actieradius is afhankelijk van de soort en de periode (zie Tabel 6).

3) Nagaan gerealiseerde kwaliteit binnen actieradius: van alle cellen die binnen de actieradius van het territorium vallen, wordt nagegaan wat de gerealiseerde kwaliteit is. De gerealiseerde kwaliteit wordt vervolgens vermenigvuldigd met de oppervlakte van de cel $(=625 \mathrm{~m} 2)$. Op deze manier wordt rekening gehouden met de kwaliteit van het bereikbare foerageerhabitat (1 hectare 'uitgesteld maaien' heeft een grotere betekenis als foerageerhabitat voor weidevogelkuikens dan 1 hectare 'legselbeheer').

4) Optellen beschikbaar foerageerhabitat: de totale hoeveelheid beschikbaar foerageerhabitat per territorium wordt uitgerekend door de oppervlaktes van alle cellen bij elkaar op te tellen (gewogen naar gerealiseerde kwaliteit). De resulterende som is de gewogen hoeveelheid kuikenland per territoria. Daarbij wordt ook rekening gehouden met concurrentie, bij claims van meerdere territoria (vanwege overlappende actieradius) worden de aantal hectares verdeeld over de territoria.

Voor meer informatie: zie Schotman et al. (2008 en 2005); Melman et al. 2009.

Tabel 6 Deze tabel geeft de actieradius per soort en per periode ( $1=$ tot half mei, $2=2^{\mathrm{e}}$ helft mei, 3 = vanaf 1 juni) weer. In de laatste kolom wordt weergegeven hoeveel \% van de gezinnen binnen de gekozen actieradius actief is (Schotman et al. 2008; Melman et al. 2009).

\begin{tabular}{|c|c|c|c|}
\hline Soort & Periode & Actieradius & $\%$ gezinnen \\
\hline Kievit & 1 & 300 & 75 \\
\hline Kievit & 2 & 300 & 75 \\
\hline Kievit & 3 & 500 & 50 \\
\hline Grutto & 2 & 300 & 75 \\
\hline Grutto & 3 & 500 & 50 \\
\hline Tureluur & 3 & 500 & 75 \\
\hline Scholekster & 1 & 200 & 50 \\
\hline Scholekster & 2 & 200 & 75 \\
\hline Scholekster & 3 & 200 & 75 \\
\hline
\end{tabular}

\section{$5.3 \quad$ Kentallenanalyse}

\section{Definitie \& belang}

De kentallenanalyse visualiseert automatisch (door middel van figuren) een aantal belangrijke kentallen omtrent weidevogelbeheer, te weten:

1. Beheer: Oppervlak (ha) per beheerpakket (greppel plas-dras, plas-dras, uitgesteld maaien $<15$ juni, uitgesteld maaien > 15 juni, legselbeheer, overig).

2. Weidevogels, aantallen, dichtheden en BTS: Aantal broedpaar, dichtheid per hectare. BTS gegevens dienen zelf te worden aangevuld.

3. Potentiële kwaliteit: Oppervlak (ha) per kwaliteitscategorie (zeer laag, laag, redelijk, goed).

4. Verdeling beheer over potentiële kwaliteit: Oppervlak (ha) zwaar beheer, licht beheer, geen beheer per kwaliteitscategorie van de potentiële kwaliteit (ligt het beheer op de juiste plek?).

5. Gerealiseerde kwaliteit: Oppervlak (ha) per kwaliteitscategorie (zeer laag, laag, redelijk, goed).

6. Verdeling territoria over gerealiseerde kwaliteit: Aantal territoria per kwaliteitscategorie (gerealiseerde kwaliteit). 
7. Aanbod kuikengrasland: Aantal hectares kuikengrasland per weidevogelterritoria.

Wat bovenstaande kentallen betekenen, wordt toegelicht in de output van de kentallenanalyse (Excelbestand). Door de cursor van de muis op een van de vraagtekens te houden die aan de rechterbovenzijde van ieder figuur staan, verschijnt uitleg over het belang en de wijze waarop de figuur kan worden geïnterpreteerd.

\section{Werkwijze}

De kentallenanalyse is op dit moment nog in ontwikkeling. [werk in uitvoering]

\section{Mogelijkheden analyse}

De output van de kentallenanalyse geeft in één oogopslag een beeld van de kwaliteit van een weidevogelgebied. De figuren kunnen tevens worden gebruikt voor verslaglegging (onder vermelding van het volgende: bron= kennissysteem Beheer op Maat, Wageningen Environmental Research, geraadpleegd op $x x-x x-x x x)$. 


\section{Literatuur}

Onderstaande tabel geeft een overzicht van de belangrijkste rapporten omtrent de ontwikkeling van het kennissysteem Beheer op Maat. Alle rapporten zijn te downloaden door de link uit de kolom 'download' te kopiëren in de adresbalk van en webbrowser.

2017 Melman, Th.C.P., A.G.M. Schotman, B. Vanmeulebrouk, I. Staritsky, H.A.M. Meeuwsen, 2017. http://edepot.wur.nl Kennissysteem agrarisch natuurbeheer: aandacht voor inpasbaarheid en validatie. $/ 408667$ Wageningen, Wageningen Environmental Research, Rapport 2791.

2017 Melman, Th.C.P. \& H. Sierdsema, 2017. Weidevogelscenario's: Mogelijkheden voor aanpak van verbetering van de weidevogelstand in Nederland. Wageningen, Wageningen Environmental Research, Rapport 2796.

2015 Schotman, A.G.M., Th.C.P. Melman, J.H. Ringrose, H.A.M. Meeuwsen, B. Vanmeulebrouk, W. Nieuwenhuizen, 2015. Beheer op Maat, op weg naar lerend beheer voor weidevogels. Wageningen, Alterra Wageningen UR (University \& Research Center), Alterra-rapport 2643.

2014 Melman, Th.C.P., H. Sierdsema, R. Buij, G. Roerink, H. ten Holt, S. Martens, H.A.M. Meeuwsen, A.G.M Schotman, 2014, Uitwerking kerngebieden weidevogels; -peiling draagvlak bij provincies; -verbreding kennissysteem BoM. Wageningen, Alterra Wageningen UR (University \& Research centre), Alterra-rapport 2564.

2013 Sierdsema, H., A.G.M. Schotman, E.B. Oosterveld en Th.C.P. Melman, 2013. Weidevogelkerngebieden Noord-Holland; vergelijking van vier scenario's. Wageningen, Alterra, Alterra-rapport 2435; Sovon-rapport 2013/23; A\&W-rapport 1899.

2012 Teunissen, W.A., A.G.M. Schotman, L.W. Bruinzeel, H. ten Holt, E.O. Oosterveld, H.H. Sierdsema, E. Wymenga en Th.C.P. Melman, 2012. Op naar kerngebieden voor weidevogels in Nederland. Werkdocument met randvoorwaarden en handreiking. WebQuery/wurpubs/ fulltext/417827 http://edepot.wur.nl /344835 Wageningen, Alterra, Alterra-rapport 2344. Nijmegen, Sovon Vogelonderzoek Nederland, Sovon-rapport 2012/21, Feanwâlden, Altenburg \& Wymenga ecologisch onderzoek, A\&Wrapport 1799.

2011 Meeuwsen, H.A.M. \& R. Jochem, 2011. Openheid van het landschap; Berekeningen met het model Viewscape. Wageningen, Wettelijke Onderzoekstaken Natuur \& Milieu, WOtwerkdocument 281.

http://edepot.wur.nl /317059 http://edepot.wur.nl $/ 260929$

http://library.wur.nl/ WebQuery/wurpubs/ fulltext/240248

009 Melman, D., M. Kiers, H. Meeuwsen, A. Schotman, H. Sierdsema, B. Vanmeulebrouk P. Wiersma, 2009. Werkzaamheden weidevogelonderzoek BO-2008; voortgangsrapportage

http://library.wur.nl/ WebQuery/edepot/4 2221 Beheer-op-maat 2008: naar identificatie kerngebieden weidevogelbeheer. Wageningen, Alterra, Alterra-rapport 1865.

2008 Schotman, A.G.M, Th.C.P. Melman, S.R. Hensen, M.A. Kiers, H.A.M. Meeuwsen, O.R. Roosenschoon \& B. Vanmeulebrouk, 2008. Het grutto-mozaïekmodel als kwaliteitstoets weidevogelbeheer; ontwikkelingen en toepassingen 2004-2008. Wageningen, Alterra, Alterrarapport 1408 .

2007 Kleijn, D., Dimmers, W., van Kats, R., Melman, D. \& Schekkerman, H., 2007. De voedselsituatie voor gruttokuikens bij agrarisch mozaiekbeheer. Wageningen, Alterra, Alterra-rapport 1487.

2007 Schotman, A.G.M., M.A. Kiers \& Th.C.P. Melman, 2007. Onderbouwing gruttogeschiktheidskaart; Ten behoeve van Grutto mozaïekmodel en voor identificatie van weidevogelgebieden in Nederland. Wageningen, Alterra, Alterra-rapport 1407.

http://edepot.wur.nl $/ 8137$

http://edepot.wur.nl 13870 A.G.M. Schotman, Th.C.P. Melman, 2006. Haalbaarheidsstudie nieuw weidevogelgebied. Wageningen, Alterra, Alterra-Rapport 1336.

http://library.wur.nl/ WebQuery/wurpubs/ fulltext/42221 http://library.wur.nl/ WebQuery/edepot/4 $2221 \% 20(2007$ http://library.wur.nl/ WebQuery/edepot/2 8518

2005 Schotman, A.G.M., Th.C.P. Melman, H.A.M. Meeuwsen, M.A Kiers \& H. Kuipers, 2005. Naar een Grutto-mozaïekmodel; Definitie van een model voor evaluatie vooraf van de effectiviteit van mozaïekbeheer. Stand van zaken juni 2005. Wageningen, Alterra, Alterra-rapport 1199. 


\section{Bijlage 2 Verslag werkplaatsen BoM}

(auteurs: Astrid Manhoudt en Imra Klein, HVHL-Leeuwarden)

\section{Samenvatting}

Collectieven ervaren het werken met Beheer op Maat zinvol: ze kunnen nu op een geobjectiveerde manier kijken naar de basiskwaliteit en de gerealiseerde beheerkwaliteit in hun gebieden. Het kennissysteem brengt concreet in beeld waar verbeteringen in beheer nodig zijn en/of bevestigt dat de collectieven het beheer op orde hebben. Echter, de eigen gebiedskennis van het collectief is essentieel om de basiskwaliteitskaarten en de analyse van het gerealiseerde beheer en de stippen op waarde te schatten en te interpreteren.

De collectieven zien het kennissysteem als een praktisch hanteerbare leidraad om hen te helpen het beheer verder te verbeteren. De collectieven willen het kennissysteem graag gebruiken voor verschillende doeleinden bij het weidevogelbeheer:

- Het plannen van het beheer;

- Evaluatie van het jaarlijkse beheer;

- Het verbeteren van het lastminutebeheer;

- Het invullen en uitwerken van het beheer in compensatiegebieden;

- Onderbouwen van noodzakelijk wijzigingen in beheer per deelnemer of per gebied;

- Verantwoorden aan derden zoals provincies, vrijwilligersorganisaties en gebiedspartijen zoals de terreinbeherende organisaties.

Het kennissysteem kan de collectieven helpen in de communicatie naar diverse partijen, zoals de eigen deelnemers, nieuwe deelnemers, terreinbeheerders, provincie of andere overheden. Het systeem maakt inzichtelijk hoe het beheer georganiseerd is, welke verbeteringen in het beheer nodig zijn en/of soms andersom welke beheer overbodig is in een bepaald gebied.

De collectieven vinden het echter niet wenselijk dat de overheid dit systeem als een beoordelingsmiddel gaat gebruiken, maar dat het een tool blijft voor de collectieven om de gebieden met beheer beter in kaart te brengen, de eigen gebieden te kunnen toetsen, maar ook om gebieden tussen collectieven te kunnen benchmarken.

Het kennissysteem maakt inzichtelijk dat het werken met actuele, betrouwbare en nauwkeurige gegevens essentieel is. Veel opmerkingen tijdens de werkplaatsen hebben betrekking op niet-volledige of niet-actuele gegevens. De juiste gegevens moeten actueel beschikbaar zijn om een zinvolle analyse uit te kunnen voeren.

Daarnaast moeten de gegevens eenduidig zijn: een uniforme aanpak van de beheermonitoring is hiervoor de basis. Door samen te werken met andere collectieven, LandschappenNL en SOVON, kunnen hier de komende tijd nog stappen in gemaakt worden.

De kaarten en de analyses bevestigen vaak wat de collectieven zelf al waarnemen in hun gebieden, maar zijn door niet up-to-date informatie in de basisbestanden niet $100 \%$ betrouwbaar. Zonder de eigen gebiedskennis van het collectief kunnen de basiskwaliteitskaarten niet op waarde worden geschat of geïnterpreteerd.

In de werkplaatsen zijn door de collectieven tal van verbetersuggesties gegeven. Deze hebben zowel op het kennissysteem zelf betrekking als op de organisatie van de ontsluiting van de benodigde gegevens. De verbetersuggesties voor het kennissysteem Beheer op Maat gingen over:

- de gebruikersvriendelijkheid van het systeem;

- de presentatie van diverse kaartlagen;

- het inzichtelijk maken van de gehanteerde methoden om tot bepaling van de basiskwaliteit en de gerealiseerde kwaliteit te komen;

- de mogelijkheid om eigen gegevens te uploaden.

De verbetersuggesties voor de ontsluiting van de diverse gegevens waren:

- directe aansluiting op de beheergegevens zoals die in SCAN-Office aanwezig zijn; 
- directe aansluiting om weidevogelgegevens van SOVON, FFVW, LandschappenNL te kunnen gebruiken;

- zorgen voor up-to-date bestanden voor ontwatering, openheid, verstoring en zwaarte gewas;

- mogelijkheid om deze 'centraal ontsloten' gegevens te kunnen overrulen met eigen gegevens.

\section{Aanleiding}

In het kader van het project Werkplaatsen Beheer op Maat zijn in het voorjaar van 2017 werkplaatsen voor de weidevogelcollectieven georganiseerd door Hogeschool Van Hall Larenstein, Wageningen Environmental Research (Alterra) en BoerenNatuur. In de werkplaatsen zijn de collectieven aan de slag gegaan met het Kennissysteem Beheer op Maat op basis van hun eigen velddata. Het kennissysteem is ontwikkeld door Wageningen Environmental Research. De kern van het kennissysteem zijn de rekenregels om habitatkwaliteit en beschikbaarheid kuikenland voor weidevogelgezinnen te bepalen.

Het doel van de werkplaatsen was:

1. Inzichtelijk maken van habitatkwaliteiten in voor weidevogels beheerde gebieden; analyse in hoeverre aan 'minimumeisen' wordt voldaan. In hoeverre komt de informatie op de Alterrakaarten overeen met de eigen gebiedsinzichten?

2. Inzicht creëren in afwegingen/factoren die bepalen op welke locatie een bepaalde beheermaatregel wordt uitgevoerd.

3. Benchmark tussen collectieven: vergelijking en bespreking van beheerde gebieden m.b.v. kentallen. Dit om verbeteringsmogelijkheden in aanpak en uitvoering van het beheer scherp te krijgen.

In totaal zijn er 7 werkplaatsen georganiseerd, die bezocht zijn door 30 collectieven met weidevogelbeheer en daarnaast door diverse vertegenwoordigers van de provinciale landschappen en/of landschapsbeheerorganisaties (voor aanwezige organisaties zie het overzicht in de Bijlage 1). In elke werkplaats werd aan de hand van drie stappen het kennissysteem uitgelegd:

1. De basiskwaliteitskaarten

2. De gerealiseerde habitatkwaliteit

3. De geanalyseerde stippenkaart

Hieronder volgt een verslag van de bevindingen en ervaringen uit de werkplaatsen gebundeld per thema van de werkplaats.

\section{Eerste indrukken uit de werkplaatsen}

Uit de 'Ex-ante-evaluatie ANLb-2016 voor lerend beheer' (Melman et al. 2016) blijkt dat er een groot verschil is tussen waar het beheer ligt én waar de geschiktste locatie op basis van ontwatering, openheid, grasgroei, verspreiding van de vogels en andere factoren is. Ongeveer $40 \%$ van het weidevogelbeheer ligt buiten kansrijk gebied en dus op minder geschikte locaties. We verwachten dat hier, naast de deelnamebereidheid van de boeren, ook meespeelt dat in het veld een ander beeld leeft over wat geschikt habitat is dan Alterra/Sovon op basis van (a)biotische gegevens als uitgangspunt heeft genomen.

Er zijn 7 werkplaatsen georganiseerd. Alle weidevogelcollectieven (op één collectief na) hebben de werkplaatsen bijgewoond. Tijdens deze werkplaatsen waren de collectieven in het begin zeer kritisch over het kennissysteem, vaak nog gebaseerd op eerdere ervaringen met het systeem, dat toen nog sterk in ontwikkeling was.

Aan het einde van de workshop was iedereen enthousiast en op een betrokken manier met het systeem bezig. Uiteindelijk wilde men graag thuis verder met het systeem aan de slag. Elke werkplaats resulteerde dan ook automatisch in een wensenlijstje van wensen voor het gebruik, verbeterpunten of nieuwe functionaliteiten in het systeem.

Hieronder wordt per onderdeel besproken welke opmerkingen de collectieven hebben gegeven. Deze onderdelen zijn:

1. het kennissysteem en de functionaliteiten;

2. de data t.b.v. het systeem;

3. de analyses van de kaarten. 
Elke onderdeel wordt afgesloten met een overzicht van de verbeterpunten.

\section{Het kennissysteem en de functionaliteiten}

Via een link kunnen alle collectieven vanuit hun eigen kantoor het kennissysteem benaderen, hierdoor was het ook mogelijk om op verschillende locaties de werkplaatsen te organiseren.

Het systeem werkt op zich prima, maar op onderdelen is verbetering wenselijk. Afhankelijk van het type pc en de webbrowser, functioneerde het systeem niet altijd. De browser Google Chrome lijkt het geschiktst. Daarnaast is het niet duidelijk wanneer het systeem bijvoorbeeld aan het rekenen is of kaarten aan het laden is. Een snelle internetverbinding is noodzakelijk om goed en met plezier aan de slag te kunnen.

Het systeem is in de huidige vorm niet startklaar om bij de collectieven direct te gaan gebruiken. Data-invoer kan niet zelfstandig gedaan worden door de collectieven en/of worden nog niet automatisch geladen. Basisgegevens, zoals de begrenzing van werkgebieden, ontbreken nog op dit moment. Daarnaast wordt een andere indeling in beheer gehanteerd dan de collectieven zelf gebruiken op basis van de beheerpakketten.

Bij het wisselen van de kaarten springt de locatie terug naar de startlocatie, waardoor elke keer opnieuw het eigen werkgebied opgezocht moet worden (dit is inmiddels opgelost).

Ondersteuning bij het gebruik van het kennissysteem is noodzakelijk wanneer we de collectieven zelf aan de slag willen laten gaan met het kennissysteem.

Randvoorwaarde: Update software.

Het kennissysteem maakt gebruik van Flash, een verouderde, niet meer ondersteunde programmeertaal. Voor aanpassingen is omzetting naar een nieuwe taal noodzaak (Ext]S 6.2, dat hiervoor het meest geschikt is). Hier wordt op dit moment ook al aan gewerkt (28-06-2017).

\section{Wensen en/of aandachtspunten kennissysteem}

- Handleiding: Een duidelijke (beknopte) handleiding is belangrijk voor de collectieven waarin beschreven wordt hoe het systeem stap voor stap werkt.

- Uitgangspunten: Inzichtelijk maken welke uitgangspunten/aannames de basis vormen voor de analyses van de kaarten ten aanzien van de verschillende factoren in het systeem. Bijv. bij 'verstoring' is niet duidelijk tot welke afstand de verstoring is meegenomen in het systeem voor doorgaande wegen, rietkragen, bomen etc. Definities en omschrijvingen van begrippen, criteria en wegingsfactoren moeten inzichtelijk zijn.

- Basiskwaliteitskaarten: Om een goed beeld te krijgen van de impact van verschillende factoren als drooglegging, verstoring, productie etc. zou het fijn zijn om een functie toe te voegen aan het systeem waarbij de verschillende factoren uit- en aangezet kunnen worden. Op deze manier kan gemakkelijker de betekenis van een bepaalde factor achterhaald worden waarom een gebied nu juist wel of niet geschikt is. Door bepaalde factoren uit te sluiten, kan ook een betere beoordeling gemaakt worden van het benodigde lastminutebeheer tijdens het seizoen.

- Referentiemateriaal: Een toevoeging van beeldmateriaal waarop duidelijk zichtbaar is hoe een nat/kruidenrijk gebied eruitziet voor de weidevogel. Dit vergemakkelijkt de communicatie met grondbezitters die vaak een ander referentiebeeld hebben.

- Zandlopertje: Verstandig om een zandlopertje in beeld te krijgen als het systeem aan het laden is. Daardoor is duidelijk dat de nieuwe kaart nog niet geladen is, maar het systeem wel bezig is deze op te halen.

- Upload actuele, zelf verzamelde gegevens: mogelijkheid voor collectieven om actuele gegevens in te voeren en te gebruiken bij de analyse.

- Helpdesk/vraagbaak: bij verdere uitrol van het kennissysteem is technisch/inhoudelijke ondersteuning nodig, bijvoorbeeld in de vorm van een helpdesk of een mailadres waar men terechtkan voor vragen.

\section{Data}

Evaluatie van beheerplannen met BoM maakt duidelijk hoe belangrijk beschikbaarheid van betrouwbare en actuele data is. In de voorbereiding van de werkplaatsen bleek het erg lastig om de juiste data op het juiste moment beschikbaar te krijgen.

BoM maakt voor het in beeld brengen van de basiskwaliteit nu gebruik van openbare gegevens op landelijke schaal, zoals droogleggingskaarten en grasgroeikaarten die beschikbaar zijn in het systeem. 
In sommige gevallen zijn provinciaal soms actuelere gegevens beschikbaar zijn, bijvoorbeeld bij het Geo Portaal Drenthe. Idealiter zouden dergelijke data voor dit doel ontsloten moeten zijn.

Sommige data zijn openbaar, andere, zoals het beheer per perceel, de beheermonitoring en de weidevogelgegevens, zijn eigendom van de collectieven, al of niet in samenwerking met de provinciale landschappen, landschapsbeheerorganisaties of de BFVW. Deze gegevens zijn in verschillende databases geregistreerd, die op dit moment niet met elkaar communiceren. In dit project is het organiseren en beschikbaar krijgen van de data ad hoc door Van Hall Larenstein geregeld en zijn de bijkomende kosten voor het aanleveren van de data ook vergoed door het project.

Tijdens de werkplaatsen bleken niet alle data up-to-date of compleet te zijn. Ook worden er nog verschillende telmethoden gehanteerd afhankelijk van het gebied, de beschikbaarheid en professionaliteit van de collectieven en vrijwilligers en de manier waarop het collectief de monitoring heeft georganiseerd. Het is ook nog niet vanzelfsprekend dat alle data actueel digitaal worden vastgelegd door de vrijwilligers, waardoor analyses tijdens het weidevogelseizoen lang niet altijd representatief zijn voor de weidevogels en het benodigde beheer. De actualiteit van die gegevens is dus afhankelijk van de manier waarop de collectieven dit zelf willen organiseren. Beheerpakketten en de afspraken per perceel moeten compleet en actueel zijn in het systeem. Daarnaast is het belangrijk dat de gegevens betrouwbaar zijn en dat de tellingen/metingen in het veld goed worden gedaan. Ten slotte zijn niet altijd actuele kaarten beschikbaar. Daarom kan het soms handig zijn dat de collectieven zelf op basis van kennis en ervaring kaarten kunnen aanpassen aan de actualiteit in het gebied. Hierdoor kan het collectief bijvoorbeeld zelf opgaande begroeiing of extra watermaatregelen toevoegen of verwijderen, waardoor de kaarten beter overeenkomen met de werkelijkheid en er dus een betrouwbaardere analyse gemaakt kan worden.

\section{Wensen en/of aandachtspunten data}

- Databeschikbaarheid: Duidelijke afspraken gewenst over eigendom en beschikbaarheid van telgegevens.

- Type data: aangeven welke data (territoriagegevens) nodig zijn voor evaluatie van beheer in BoM; bij voorkeur wordt dit ook in het kennissysteem aangegeven als service aan de gebruikers.

- Koppeling van systemen: automatische actuele data-uitwisseling tussen de databases mogelijk maken voor de beheergegevens, de monitoringgegevens en het kennissysteem.

- Bewerking van data: optioneel moeten verouderde kaarten handmatig aangepast kunnen worden.

- Dataverzameling: verbeteren, uniformeren en actualiseren van de tel- en registratiemethoden.

\section{De kaarten}

\section{De basiskwaliteitskaarten}

Vanuit de collectieven is gebleken dat de informatie op de Alterra-kaarten over het algemeen goed overeenkomt met de werkelijkheid. Op de basiskaarten waren evenwel ook onderdelen die in detail niet overeenkwamen met de praktijk volgens de aanwezige collectieven. Hieronder worden deze per onderwerp besproken.

\section{Droogleggingskaart}

Deze kaart is vrij grof, waardoor niet alle sloten goed worden aangegeven. Plekken op de kaarten zijn minder droog in de werkelijkheid dan door het systeem aangegeven. Dorpen en bos zijn aangegeven als natte delen.

\section{Openheid}

Een stukje bos of boomwal op het perceel staat als helemaal open in het systeem, er missen dus details (terwijl deze details heel belangrijk zijn voor het predatie risico). Daarnaast worden bomenrijen soms als 1 stip weergegeven, terwijl dit beter als losse bomen kan. Ook ontbreken solitaire bomen nog weleens.

\section{Grasgroeikaart}

Het gebruik maken van grasgroeigegevens op basis van satellietopnamen is een innovatief onderdeel in BoM. De zwaarte van het gewas wordt in BoM bepaald op basis van het volume gras dat op de satellietfoto's van de tweede helft van april is waargenomen gemiddeld over een periode van drie jaar (nu van 2013 tot 2015). De gehanteerde index ontbreekt in het systeem op dit moment. 
Het gewas wordt soms als zwaarder aangemerkt dan de collectieven het in werkelijkheid ervaren, dit kan komen doordat de kaart gebaseerd is op een gemiddelde van drie jaar. Op sommige percelen wordt echter zo vroeg gemaaid (voor half april) dat het kennissysteem het perceel vanwege de geringe biomassa als geschikt aanmerkt, terwijl het vanwege de zeer vroege maaibeurt volledig ongeschikt is als weidevogelbiotoop.

Volgens de collectieven is het nemen van het gemiddelde over drie jaar niet altijd even gelukkig, omdat daarmee de situatie in een specifiek jaar niet correct wordt weergegeven.

\section{Verstoring}

Verstoring door bomen wordt op de kaart veelal groter weergegeven dan men in de praktijk ervaart. Ditzelfde geldt voor een (laag gelegen) fietspad/spoorlijn die door het gebied loopt. In veel gebieden, die als verstoord uit de analyse komen, komen toch grutto's voor. De collectieven hebben het idee dat de verstoring als factor nu te zwaar meeweegt in het systeem dan het in de werkelijkheid effect heeft. Verstoring en openheid lijken een overlap te hebben, waardoor dit extra zwaar weegt in de waardering van een gebied. Dit kan een vertekend beeld geven.

\section{Wensen en/of aandachtspunten basiskaarten}

Toevoegingen aan de basiskaarten: Door extra informatie in aparte lagen toe te voegen aan het systeem kan meer informatie betrokken worden in de analyses, zoals:

- Topografische laag, waardoor gemakkelijker te bepalen is welke locaties je bekijkt (deze kaart moet gemakkelijk met een schuivertje aan en uit gezet kunnen worden);

- een bodemkaart (+ vruchtbaarheid);

- de actuele waterstanden;

- Beheergegevens uit SCAN-office:

- Grasgroei: de kruidenrijkdom inzichtelijk maken gekoppeld aan de grasgroei.

- Overige factoren: hoe predatie en/of schade door ganzen inzichtelijk te maken?

- Grasgroei: naast de grasgroeikaart gebaseerd op een gemiddelde van drie jaar, kan ook de actuele grasgroei per jaar op basis van eind april/begin mei handig zijn om beschikbaar te hebben.

- Verstoring/openheid: onderscheid tussen beide factoren zo scherp mogelijk maken en, indien aanwezig, overlap eruit halen om te zware weging te voorkomen.

\section{Stap 2: Gerealiseerde habitatkwaliteit}

Deelnemers ( $h$ )erkennen de bereidheid van agrariërs om deel te nemen aan ANB in kansrijke gebieden een belangrijk onderdeel is om de basiskwaliteit te kunnen realiseren. Deze kaart geeft een goed beeld van het nut om beheer op bepaalde locaties juist wel of niet af te sluiten. Inpasbaarheid in de bedrijfsvoering blijft een knelpunt. Toch is te zien dat op minder geschikte locaties het juist nuttig kan zijn om beheer af te sluiten, omdat de nesten zich daar wel bevinden en gecombineerd met een gedreven boer ook goed beschermd worden.

De deelnemers hebben vaak een andere referentiebeeld: zij noemen iets al snel 'nat' of 'kruidenrijk'. De kaarten kunnen bijdragen om een beter beeld te vormen. Zeker als er nog beeldmateriaal wordt toegevoegd.

Alternatief beheer bijvoorbeeld voor weidevogels op bollenland komt nu slecht uit de analyse, terwijl daar wel veel vogels zitten.

Op dit moment is enkel de soort grutto opgenomen in het systeem. Een toevoeging van meerdere soorten zoals akkervogels en de veldleeuwerik zou het systeem completer maken.

\section{Wensen en/of aandachtspunten}

- Soortenanalyse: uitbreiding naar andere soorten scholekster, kieviet maar ook akkervogels en veldleeuwerik;

- Beheer op akkerland: beoordeling van akkerland meenemen in de analyses.

\section{Stap 3: Geanalyseerde stippenkaart}

Deze kaarten geven een goed beeld van de aanwezige grutto's in het gebied en maken inzichtelijk of er voldoende beheer beschikbaar is om aanwezige grutto's te beschermen. Daarnaast kunnen deze gegevens goed gebruikt worden voor de onderbouwing van de gebiedsaanvraag. 
Het beeld uit de geanalyseerde stippenkaarten sluit goed aan bij wat de collectieven zelf ervaren over hun gebied. Er worden daardoor weinig zaken benoemd die niet kloppen.

De werkgebieden waarbinnen een analyses wordt gedaan moeten handmatig ingetekend worden. Bekeken moet worden of de telgebieden in de database LandschappenNL hier mogelijk voor gebruikt kunnen worden of anders de deelgebieden in SCAN Office.

De weidevogeltellingen en de beheergegevens van de natuurterreinen ontbreken in de analyses, omdat van deze gebieden geen data beschikbaar waren voor de werkplaatsen. Voor een goede gebiedsanalyse moeten deze gegevens ook meegenomen kunnen worden, omdat het beheer voor natuur en agrarische natuur elkaar versterkt en ook op elkaar afgestemd zou moeten worden. Op dit moment missen er zeker nog wel stippen, waardoor sommige analyses geen actueel beeld geven, maar de analyse bevestigt volgens de collectieven wel de huidige situatie.

In de analyse wordt per aanwezige broedpaar beoordeeld of deze voldoende beschermd is op die specifieke locatie. Het is dan niet meteen duidelijk waar het knelpunt zit voor die specifieke locatie. Collectieven hebben de behoefte om per stip inzichtelijk te krijgen wat het probleem kan zijn. Sommige stabiele weidevogelgebieden hebben zulke hoge dichtheden grutto's dat deze toch negatief uit de analyse komen, omdat de norm voor het hoeveelheid kuikenland per gruttopaar niet gehaald wordt. Aanpassing van de grenswaarde voor de hoeveelheid kuikenland zou in sommige gevallen mogelijk moeten zijn.

Op basis van deze gegevens kun je een nieuw gebied onderzoeken voor het afsluiten van beheer en in beeld krijgen hoeveel beheer en welk type beheer nodig is voor de aanwezige grutto's. De gebiedscoördinator of veldmedewerker kan de analyse uit het systeem ook gebruiken om zijn gesprekken met de boeren te voeren.

Het systeem kan gebruikt worden om de vogelwachten uit te leggen hoe het ANLb werkt en wat de meerwaarde is van het monitoren en registreren van de veldgegevens. Daarnaast is toetsing van het aantal kuikens aan het einde van de broedperiode belangrijk om bijvoorbeeld overleving beter in kaart te kunnen brengen. Mogelijk kan dan de analyse van de stippenkaart helpen om de oorzaken scherp te krijgen.

Legselbeheer wordt niet meegenomen in de analyse van het beheer en weegt dus niet mee in de beoordeling. Het moet vooraf bekend zijn welk beheer meeweegt in de beoordeling. Het beheerpakket hoogwaterpeil wordt op dezelfde manier meegenomen als de plas-drasbeheerpakketten en weegt mee bij de watermaatregelen.

\section{Lerend beheren}

Aan de hand van de geanalyseerde stippenkaarten belandden de collectieven bijna automatisch in discussies over waar welk beheer is afgesloten en welke aanpak een collectief gebruikt voor een bepaald gebied. Ook werd er gediscussieerd over waarom bijvoorbeeld beheer werd afgesloten in minder geschikte gebieden. Juist de discussie hierover, waarom dit gebeurt, is belangrijk om onderling kennis en ervaring uit te wisselen en nieuwe inzichten op te doen. Het programma kan concreet gebruikt worden om deze discussies te voeren en van elkaar te leren.

Redenen waarom beheer op minder geschikte locaties was afgesloten, waren de inzet van een omringende schil van legselbeheer rond zwaar beheer of omdat het gebied eerder wel geschikt was, maar door toename van ganzen nu minder. In geschikte gebieden is soms juist geen beheer, omdat hier sprake is van een lage deelnamebereidheid, onder andere door weerstand voor alle bijkomende administratie, aversie richting overheidsregelingen in het algemeen, continuïteit in het beheer, de beheervergoedingen en toekomstige onzekerheden zoals de bedrijfsopvolging.

Door aan de slag te gaan met het kennissysteem Beheer op Maat nodigt het de collectieven direct uit tot reflectie over het kennissysteem, hun eigen werkwijze maar ook de werkwijze van hun collegacollectieven.

\section{Wensen en/of aandachtspunten}

- Databeschikbaarheid:

- gegevens van de terreinbeherende organisaties beschikbaar krijgen.

- SOVON-databasekoppeling mogelijk maken.

- Rechtstreeks uploaden van ANLb-beheer moet mogelijk zijn voor collectief om zelf te doen, of realtime koppeling met actueel beheer in SCAN-GIS.

- Begrenzingen: het moet mogelijk zijn om provincie of collectief grensoverschrijdend te werken.

- Werkbaarheid: het verkorten van de analysetijd. 
- Mozaïekbeheer: inzichtelijk maken welk beheer meeweegt in de analyse.

- Geanalyseerde stippen: per locatie inzichtelijk maken wat de knelpunten zijn.

- Onderscheid grutto perioden: aangeven met datum wat grutto periode 1, 2, 3 en 4 is.

\section{Afsluiting}

De collectieven willen graag aan de slag met het systeem en hebben behoefte aan duidelijkheid wanneer en in welke vorm het kennissysteem beschikbaar kan komen voor hen. Liefst wil men het kennissysteem gebruiken om aan het einde van het weidevogelseizoen 2017 het beheer voor volgend jaar te gaan verbeteren.

VHL/WUR

dd. 28-06-2017 


\section{Bijlage 3 Voorstel voor kentallen BoM}

In 2017 is het idee ontstaan om een kentallenanalyse toe te voegen aan de BoM-systematiek. Deze analyse berekent de meest essentiële kentallen rondom het weidevogelbeheer en visualiseert deze door middel van een aantal eenvoudig te interpreteren en te vergelijken figuren. Het doel van de kentallenanalyse is om in één oogopslag een indruk te krijgen van de kwaliteit van een weidevogelgebied. Door de kentallenanalyse jaarlijks uit te voeren, kan de gebruiker bijhouden hoe het gebied zich ontwikkelt.

Het $1^{\mathrm{e}}$ concept voor de kentallenanalyse is weergegeven op de volgende pagina. Hieronder volgt een korte toelichting bij de figuren:

1. Beheer: Aantal hectare per beheerpakket, binnen geselecteerd deelgebied, op basis van recentst aangeleverde beheermozaïek. Geeft inzicht in de verhouding tussen zwaar en licht beheer.

2. Weidevogels: Aantallen, dichtheid en BTS: Ontwikkelingen weidevogelpopulatie per soort (aantallen, dichtheden en bruto territoriaal succes). Maak gebruik van de selectieknop 'Jaar' om te kiezen voor een specifiek broedseizoen of voor het langjarig gemiddelde. Geeft inzicht in de ontwikkelingen van de weidevogelpopulatie.

3. Potentiële kwaliteit: De potentiële kwaliteit is de combinatie van drooglegging, openheid, verstoring en de voedselrijkdom van de bodem. In het geval dat alle vier de factoren op orde zijn, wordt een hoge potentiële kwaliteit toegeschreven aan de locatie in kwestie. Wanneer een of meerdere factoren niet optimaal zijn, neemt de potentiële kwaliteit van de locatie af. Binnen deze cirkeldiagram is weergegeven hoeveel hectare van het deelgebied behoort tot de vier kwaliteitscategorieën. Met behulp van de selectieknop 'beheerd/onbeheerd' kan worden gekozen of de potentiële kwaliteit van het gehele gebied of alleen van het beheerde/onbeheerde deel van het gebied wordt weergegeven.

4. Verdeling beheer over potentiële kwaliteit: Deze figuur geeft weer of de beheerpakketten op de juiste locaties liggen. De binnenste ring geeft de potentiële waarde van het gebied weer. De buitenste ring geeft weer hoeveel hectare beheer er is gelegen op/binnen iedere

kwaliteitscategorie. Daarmee kan deze figuur antwoord geven op de volgende vragen:

- Ligt het zware beheer op de correcte locaties (gebieden met een hoge/redelijke 'potentiële kwaliteit') of is het gelegen op locaties die eigenlijk minder geschikt zijn (locaties met een zeer lage/lage potentiële kwaliteit)?

- Zijn er gemiste kansen (locaties die een hoge/redelijke potentiële kwaliteit hebben waarop geen/licht beheer wordt uitgevoerd)?

5. Gerealiseerde kwaliteit: De gerealiseerde kwaliteit is de combinatie van de basiskwaliteit en het toegewezen beheer. Een hoge potentiële kwaliteit resulteert niet altijd in een hoge gerealiseerde kwaliteit. Uitsluitend wanneer de juiste (zware) beheerpakketten aan locaties met een hoge potentiële kwaliteit worden toegeschreven, wordt een hoge gerealiseerde kwaliteit bereikt (het beheer is uiteindelijk de bepalende factor). Binnen deze cirkeldiagram is weergegeven hoeveel hectare van het deelgebied behoort tot de vier kwaliteitscategorieën. Met behulp van de selectieknop 'beheerd/onbeheerd' kan worden gekozen of de gerealiseerde kwaliteit van het gehele gebied of alleen van het beheerde/onbeheerde deel van het gebied wordt weergegeven.

6. Verdeling territoria over gerealiseerde kwaliteit: Deze figuur geeft weer binnen welk van de vier categorieën van de gerealiseerde kwaliteit (zeer laag, laag, redelijk, hoog) de hoogste dichtheden weidevogels voorkomen per hectare en per soort.

7. Foerageerhabitat per weidevogelgezin: In onderstaande figuren is voor de grutto, kievit, scholekster en tureluur weergegeven hoeveel foerageerhabitat er beschikbaar is voor de kuikens. De kleuren corresponderen met de hoeveelheid hectare die beschikbaarheid is als foerageerhabitat voor een van de weidevogelgezinnen in kwestie. De grootte van de 'taartpunt' geeft weer hoeveel paar er binnen iedere categorie vallen (weergegeven in de labels is het aantal paar in de betreffende categorie. Een optimale situatie bevat zo veel mogelijk paren in de hoogste categorie ( $>1 \mathrm{ha}$ ). Bij het berekenen van de hoeveelheid hectare per weidevogelgezin is rekening gehouden met de verschillende waardes van beheerpakketten als foerageerhabitat voor weidevogelkuikens (als voorbeeld: het beheerpakket 'legselbescherming' heeft geen betekenis als foerageerhabitat voor weidevogelkuikens, in tegenstelling tot de beheerpakketten die een uitgestelde maaidatum bevatten). 


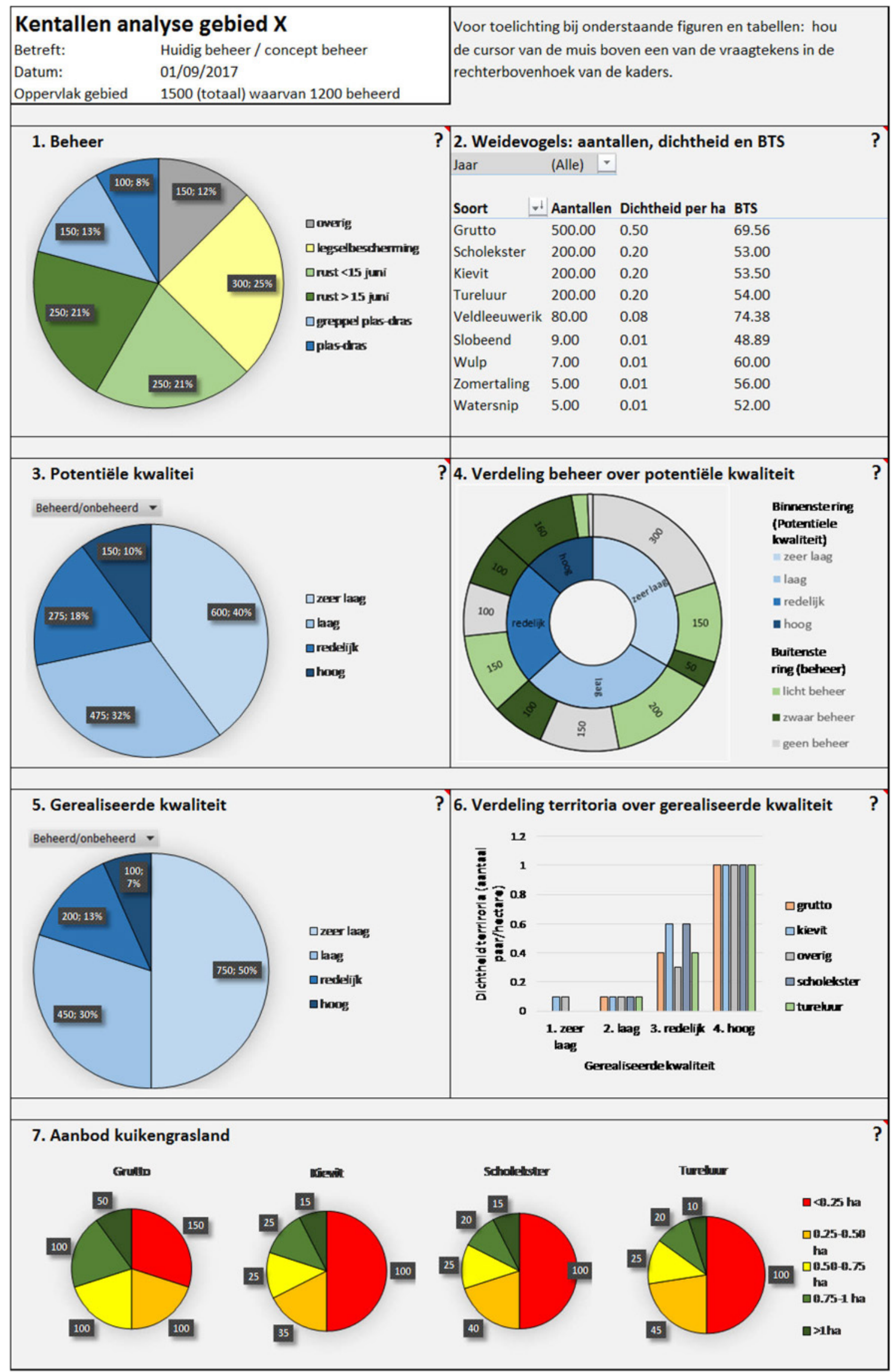

Het voornemen is om in de komende jaren verder te werken aan het automatiseren van deze analyse. Daarvoor dient het een en ander te worden geprogrammeerd, met name omtrent het op de juiste wijze wegschrijven van data in Excelsheets. Het uiteindelijke doel is dat de gebruiker de kentallenanalyse voor eigen gebied kan downladen in de vorm van een Excelbestand (binnen de webtool van BoM). 


\section{Bijlage 4 Samenvatting onderzoek greppel plas-dras}

Uit: WEnR-rapport 2845 (Visser et al. 2017)

\section{Probleemstelling en onderzoeksdoel}

Het besef dat een hoge grondwaterstand van essentieel belang is voor succesvol weidevogelbeheer dringt de laatste jaren in steeds bredere kringen door. Binnen weidevogelreservaten wordt geprobeerd een hoge grondwaterstand te bereiken door het waterpeil van de sloten te verhogen tot $+/-25 \mathrm{~cm}$ onder het maaivlak. Om dit te bereiken, dienen grootschalige ingrepen in de waterhuishouding van de polder te worden genomen, in overeenstemming met alle belanghebbenden. Bovenstaande aanpak blijkt meestal onhaalbaar voor percelen waar agrarisch natuurbeheer wordt uitgevoerd, aangezien de percelen met beheerovereenkomsten verspreid door de polder liggen en de gemiddelde moderne agrariër niet gebaat is bij het verhogen van het slootwaterpeil.

Om deze reden wordt de afgelopen tijd veel geëxperimenteerd met het 'oppervlakkig' opbrengen van water, bijvoorbeeld met behulp van een pomp op zonne-energie. Deze wijze van 'plas-drassituaties' creëren, biedt een verbeterde flexibiliteit voor de bedrijfsvoering en kan relatief eenvoudig worden toegepast op kleine schaal. Het totaal aantal greppel plas-draspercelen is in de afgelopen jaren dan ook fors toegenomen en het aanleggen en beheren van een greppelplas-dras is daarmee een veelvoorkomend onderdeel van het agrarisch natuurbeheer geworden.

Van plas-draspercelen is reeds bekend dat zij geschikt zijn als foerageerhabitat en slaap- en rustplaats voor adulte weidevogels. Over de waarde van greppel plas-draspercelen voor de kuikens van weidevogels bestaat echter veel onduidelijkheid. Het doel van dit onderzoek is om duidelijkheid te verkrijgen over de waarde van greppelplas-draspercelen voor kuikens van de grutto en andere weidevogels. Kennis over de waarde van greppelplas-draspercelen voor weidevogelkuikens is van belang, omdat:

- hiermee de vraag kan worden beantwoord of het verstandig is om deze maatregel toe te passen wanneer men beoogt geschikt foerageerhabitat voor de kuikens aan te bieden, of dat andere, potentieel waardevollere en/of goedkopere beheerpakketten de voorkeur zouden moeten krijgen.

- met voldoende kennis over de factoren die een greppelplas-dras wel/niet waardevol maken verbeterpunten wat betreft het aanleggen en beheren van greppelplas-draspercelen aan het licht kunnen komen.

\section{Onderzoeksvragen}

Hoofdvraag Welke waarde hebben percelen met een greppelplas-dras voor kuikens van de grutto? Deelvragen

1. Hoe frequent foerageren kuikens van de grutto op percelen met greppelplas- dras ten opzichte van percelen zonder greppelplas-dras?

2. Hoe verschilt de structuurrijkdom en 'doorwaadbaarheid' van de vegetatie op percelen met greppelplas-dras ten opzichte van percelen zonder greppelplas-dras?

3. Zijn verschillen in kenmerken van de greppelplas-draspercelen (oppervlakte, waterdiepte, ouderdom) van invloed op de waarde als foerageerhabitat voor weidevogelkuikens?

4. Beïnvloedt een greppelplas-dras de aanwezigheid van insecten (aantallen en biomassa)?

\section{Methode: Veldwerk}

Al het veldwerk is uitgevoerd in de Eempolders in het noorden van de provincie Utrecht, op 20 percelen met en 20 percelen zonder greppelplas-dras. Deze percelen zijn op dusdanige wijze geselecteerd dat zij ten aanzien van een aantal belangrijke omgevingsfactoren (openheid, drooglegging, voedselrijkdom, beheer etc.) zo veel mogelijk vergelijkbaar met elkaar zijn (ceteris paribus).

Op deze percelen zijn in drie rondes $\left(1^{\mathrm{e}}\right.$ ronde $=1 \mathrm{t} / \mathrm{m} 5 \mathrm{mei}, 2^{\mathrm{e}}$ ronde $=19 \mathrm{t} / \mathrm{m} 23 \mathrm{mei}, 3^{\mathrm{e}}$ ronde= 29 mei t/m 2 juni) de volgende werkzaamheden verricht:

- Alarmtellingen

De alarmtellingen zijn uitgevoerd volgens de BMP-methode en bieden inzicht in het terreingebruik 
van weidevogelgezinnen. Tijdens de tellingen is van de volgende weidevogelsoorten vastgesteld of er kuikens aanwezig zijn, op basis van het alarmgedrag van de oudervogels, op het betreffende perceel: grutto, kievit, tureluur en scholekster.

- Kenmerken greppelplas-dras

Langs een transect dat begint op het midden van het perceel (de greppel) en eindigt aan de slootkant van het perceel zijn metingen gedaan naar de ruimtelijke kenmerken van de greppel plas-dras. Hierbij is om de 1,5 m de diepte van het water gemeten. In combinatie met GIS konden de volgende variabelen worden uitgerekend voor alle 20 plas-draspercelen: breedte, diepte, oppervlakte, ouderdom (= aantal jaren dat het beheerpakket 'greppelplas-dras' is toegeschreven aan het perceel).

- Insecten (aantallen en biomassa)

Op 10 percelen met en 10 percelen zonder greppelplas-dras zijn plakvallen uitgezet. Deze plakvallen zijn na een periode van 48 uur opgehaald, waarna het aantal insecten kleiner en groter dan $4 \mathrm{~mm}$ is geteld.

- Vegetatie (structuurrijkdom, biomassa en doorwaadbaarheid)

Langs een transect dat begint op het midden van het perceel (greppel) en eindigt aan de slootkant zijn metingen gedaan naar de vegetatie. Hierbij zijn om de 1,5 m metingen verricht met een gewashoogtemeter, wat een indicatie geeft van de biomassa. Daarnaast is langs hetzelfde transect een foto-analyse uitgevoerd. Hiervoor is om de $3 \mathrm{~m}$ een foto genomen van een vegetatiestrook met een breedte van $15 \mathrm{~cm}$, met daarachter een wit schot waarop markeringen zijn aangebracht van de volgende hoogteklassen: 0-10, 10-20, 20-30, 30-40, 40-50, 50-60 centimeter. Vervolgens is binnen het analyseprogramma Image-J uitgerekend wat de dichtheid van de vegetatie is per hoogteklasse.

\section{Methode: Analyse}

Alle analyses zijn uitgevoerd met behulp van het softwareprogramma $R$. Voor het controleren van de verdeling en kenmerken van de data is gebruik gemaakt van de $R$-pakketten Rstudio en Rcommander. Voor iedere dataset (alarmtellingen, foto-analyse, schijfhoogtemetingen, insecten) zijn twee analyses uitgevoerd. Binnen de eerste analyse zijn de data van alle percelen meegenomen en is geanalyseerd of de aan- of afwezigheid van een greppelplas-dras de afhankelijke variabele beïnvloedt. Binnen deze analyse zijn ook het perceelnummer en de week meegenomen, omdat deze variabelen ook van invloed kunnen zijn op het aantal weidevogelkuikens/insecten. Binnen de tweede analyse zijn uitsluitend percelen met een greppelplas-dras opgenomen in de analyse, waarbij is geanalyseerd of verschillen in de kenmerken van percelen met greppelplas-dras (ouderdom, breedte, waterdiepte) van invloed zijn op de afhankelijke variabele. Voor het analyseren van de alarmtellingen en het aantal insecten is vanwege de herhaalde metingen gebruikgemaakt van Generalized Linear Mixed Effect Models (GLMM). Voor het analyseren van de foto en de schijfhoogtemetingen is gebruikgemaakt van Linear Mixed Effect Models (LME).

\section{Belangrijkste resultaten \& discussie}

- Zowel de grutto, kievit als de tureluur maken meer gebruik van percelen met greppelplas-dras dan van percelen zonder greppelplas-dras. Hierbij valt op te merken dat het effect het sterkst is voor de tureluur, gevolgd door de kievit en ten slotte de grutto.

- Het aantal kleine $(<4 \mathrm{~mm})$ en grote insecten $(>4 \mathrm{~mm})$ ligt hoger op percelen met greppelplas-dras dan op percelen zonder greppelplas-dras.

- De dichtheid van de vegetatie is lager op percelen met greppelplas-dras. Dit verbetert de doorwaardbaarheid van de vegetatie, wat het foerageren voor de weidevogelkuikens vereenvoudigt.

- De aanwezigheid van een greppelplas-dras resulteert in een gradiënt/mozaïek van een open/lage vegetatie in de directe nabijheid van de greppelplas-dras naar een meer gesloten/hoge vegetatie aan de randen van het perceel. Deze variatie is waardevol, omdat de kans dat een deel van het grasland geschikt is als foerageergebied voor een weidevogelkuiken (soort x, ontwikkelingsstadium $\mathrm{x}$ ) groter is als het aanbod van verschillende structuren toeneemt. Bij voldoende structuurvariatie kan een greppelplas-dras daarom zowel voldoen aan de wensen van kuikens van verschillende weidevogelsoorten als aan de wensen van kuikens van dezelfde soort die in verschillende ontwikkelingsstadia verkeren.

- Zowel het aantal insecten kleiner als het aantal insecten groter dan $4 \mathrm{~mm}$ neemt toe naarmate de ouderdom van de greppelplas-dras toeneemt. Ook het aantal paar kievit met kuikens neemt toe naarmate de ouderdom van een greppelplas-dras toeneemt, mogelijkerwijs samenhangend met de voorkeur voor korte vegetaties. 


\section{Conclusies}

Zowel de grutto, kievit als tureluur maakt meer gebruik van percelen met greppelplas-dras dan van percelen zonder greppelplas-dras. Daarnaast komen er zowel meer kleine $(<4 \mathrm{~mm})$ als grote $(>4 \mathrm{~mm})$ insecten voor op percelen met greppelplas-dras dan op percelen zonder greppelplas-dras. Ten slotte is de vegetatiestructuur op percelen met greppelplas-dras geschikter voor foeragerende weidevogelkuikens dan op percelen zonder greppelplas-dras. Dit komt ten eerste doordat de gemiddelde dichtheid van de vegetatie op percelen met greppelplas-dras lager is dan op percelen zonder greppelplas-dras, wat ten goede komt aan de doorwaadbaarheid van de vegetatie. Ten tweede komt dit doordat de variatie aan dichtheden van de vegetatie binnen het perceel groter is op percelen met greppelplas-dras dan op percelen zonder greppelplas-dras. Deze variatie is waardevol, omdat de kans dat een deel van het grasland geschikt is als foerageergebied voor een weidevogelkuiken (soort $x$, ontwikkelingsstadium $x$ ) toeneemt naarmate het aanbod van verschillende vegetatiestructuren toeneemt. Op basis van bovenstaande resultaten kan worden geconcludeerd dat percelen met greppelplas-dras een aantrekkelijker foerageerhabitat voor weidevogelkuikens vormen dan percelen zonder greppelplas-dras.

\section{Aanbevelingen voor de praktijk}

Op basis van de onderzoeksresultaten wordt aanbevolen om het aanleggen en beheren van greppelplas-dras percelen te continueren. Wat betreft de aanleg en het beheer van een greppelplasdras kunnen enkele verbeterpunten worden aangedragen:

- Bij de omvorming van reguliere percelen naar greppelplas-dras percelen kan het verstandig zijn om, alvorens de greppelplas-dras wordt aangelegd, de voedselrijkdom van de bodem flink te verlagen, door de mestgift te stoppen en frequent te maaien en afvoeren (buiten de broedperiode). Dit voorkomt dat greppelplas-draspercelen meerdere jaren blijven hangen in het gestreepte witbolstadium. Daarnaast kan hiermee worden voorkomen dat het oppervlaktewater onnodig wordt geëutrofieerd als gevolg van het uitspoelen van nutriënten.

- Houd bij de aanleg van een greppelplas-dras rekening met de geschiktheid van het perceel. Zoek naar percelen met een hol bodemprofiel en een hoog organische-stofgehalte, aangezien deze factoren het vasthouden van water vereenvoudigen. Tevens is het verstandig om percelen te selecteren met een lage voedselrijkdom en veel microreliëf, omdat deze factoren het ontstaan van een open en structuurrijke vegetatie bevorderen. Ten slotte is het verstandig om greppelplasdraspercelen aan te leggen in de nabijheid van percelen waar hoge dichtheden van broedende weidevogels voorkomen.

- De continuïteit van de maatregel is belangrijk, omdat de waarde van greppelplas-draspercelen toeneemt naarmate de ouderdom van een greppelplas-dras toeneemt. Zowel het aantal insecten kleiner als het aantal insecten groter dan $4 \mathrm{~mm}$ neemt toe naarmate de ouderdom van de greppelplas-dras toeneemt. Ook het aantal paar kievit met kuikens neemt toe naarmate de ouderdom van een greppelplas-dras toeneemt, mogelijkerwijs samenhangend met de voorkeur voor korte vegetaties.

\section{Vervolgonderzoek}

Het gebruik van plakvallen heeft inzicht geboden in de abundantie en biomassaverdeling van vliegende insecten, die het stapelvoer vormen voor kuikens van de grutto. Hiermee is echter geen (volledig) beeld verkregen van het voedselaanbod voor andere weidevogelsoorten. Plakvallen geven geen inzicht in de abundantie van insecten die zich voornamelijk over de bodem voortbewegen (relevant voor kievit en in mindere mate ook voor tureluur). Vervolgonderzoek zou zich kunnen richten op de vraag hoe het voedselaanbod voor kuikens van de kievit, tureluur en scholekster wordt beïnvloed door de aanwezigheid van een greppelplas-dras.

Alle elementen van dit onderzoek (aantal paar met kuikens, vegetatiestructuur, insectenaanbod) duiden erop dat greppelplas-draspercelen een waardevol foerageerhabitat vormen voor weidevogelkuikens. Vervolgonderzoek is nodig om erachter te komen of de geschiktheid van deze elementen daadwerkelijk leidt tot een verbetering van het foerageersucces/opgroeisucces van weidevogelkuikens die frequent gebruikmaken van percelen met een greppelplas-dras ten opzichte van weidevogelkuikens die minder frequent gebruikmaken van percelen met greppelplas-dras. Daarnaast is vervolgonderzoek nodig om te onderzoeken wat de milieubelastende effecten van greppelplas-draspercelen zijn (uitspoeling nutriënten) en hoe deze het best kunnen worden beperkt. Ten slotte is onderzoek nodig om te bepalen hoeveel greppelplas-draspercelen minimaal nodig zijn in een weidevogelgebied om voldoende foerageerhabitat voor weidevogelkuikens aan te bieden (rekening houdend met factoren als de huidige staat van het beheermozaïek, landschappelijke barrières en de dichtheid aan weidevogels). 
Wageningen Environmental Research Postbus 47

6700 AA Wageningen

T 0317480700

www.wur.nl/environmental-research

Wageningen Environmental Research Rapport 2865

ISSN 1566-7197
De missie van Wageningen University \& Research is 'To explore the potential of nature to improve the quality of life'. Binnen Wageningen University \& Research bundelen Wageningen University en gespecialiseerde onderzoeksinstituten van Stichting Wageningen Research hun krachten om bij te dragen aan de oplossing van belangrijke vragen in het domein van gezonde voeding en leefomgeving. Met ongeveer 30 vestigingen, 5.000 medewerkers en 10.000 studenten behoort Wageningen University \& Research wereldwijd tot de aansprekende kennisinstellingen binnen haar domein. De integrale benadering van de vraagstukken en de samenwerking tussen verschillende disciplines vormen het hart van de unieke Wageningen aanpak. 


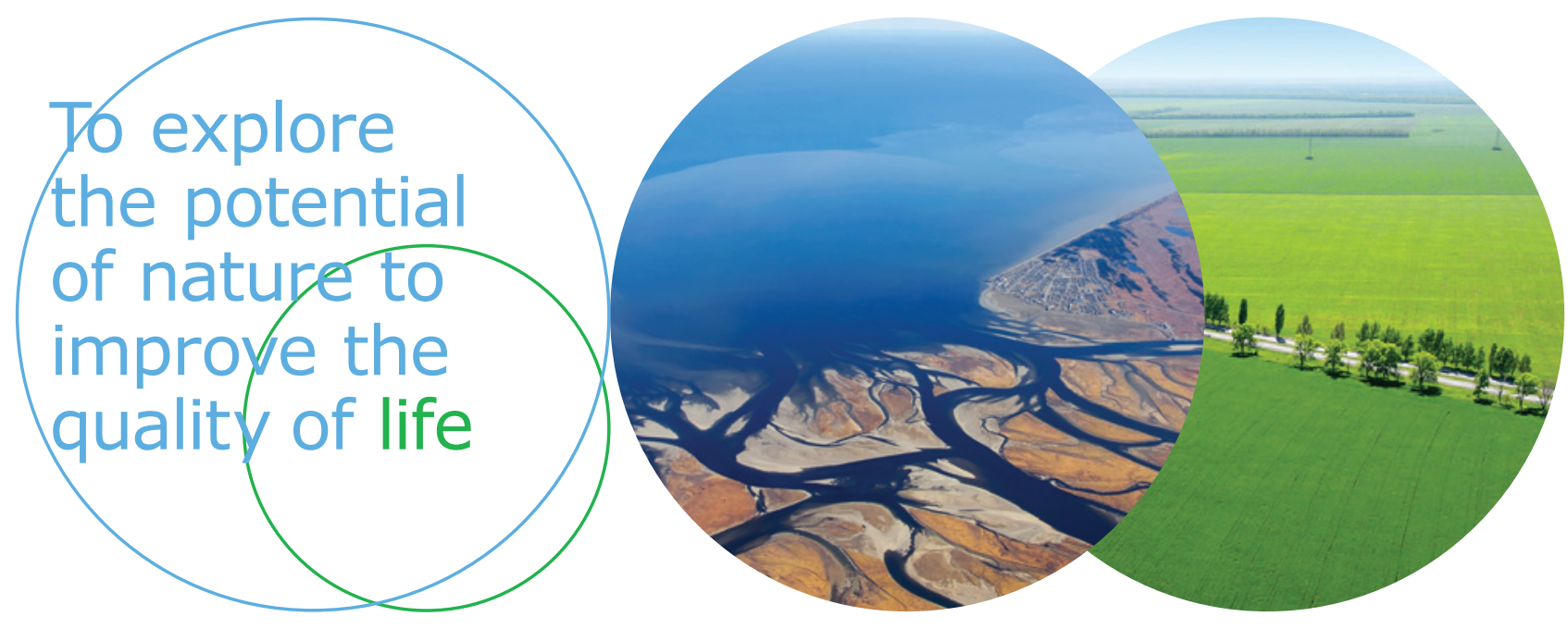

Wageningen Environmental Research Postbus 47

$6700 \mathrm{AB}$ Wageningen

T 317480700

www.wur.nl/environmental-research

Rapport 2865

ISSN 1566-7197

De missie van Wageningen University \& Research is 'To explore the potential of nature to improve the quality of life'. Binnen Wageningen University \& Research bundelen Wageningen University en gespecialiseerde onderzoeksinstituten van Stichting Wageningen Research hun krachten om bij te dragen aan de oplossing van belangrijke vragen in het domein van gezonde voeding en leefomgeving. Met ongeveer 30 vestigingen, 5.000 medewerkers en 10.000 studenten behoort Wageningen University \& Research wereldwijd tot de aansprekende kennisinstellingen binnen haar domein. De integrale benadering van de vraagstukken en de samenwerking tussen verschillende disciplines vormen het hart van de unieke Wageningen aanpak. 